\title{
Não é mais sobre
fotografia, é sobre arte
contemporânea: alguns
apontamentos Não é mais sobre
fotografia, é sobre arte
contemporânea: alguns
apontamentos Não é mais sobre
fotografia, é sobre arte
contemporânea: alguns
apontamentos Não é mais sobre
fotografia, é sobre arte
contemporânea: alguns
apontamentos
}

\section{Paula Cabral Tacca \\ Universidade Estadual de Campinas (Unicamp)}

It is no longer about photography, it is about contemporary art: some notes

\section{Resumo}

Este artigo tem por objetivo pensar a fotografia inserida no discurso da arte contemporânea, considerando que, embora o fotográfico na contemporaneidade tenha vários vieses, é na experimentação dos artistas e seus processos atuais que a fotografia se desgarra definitivamente de um lugar comum, se alocando no não específico, na fragmentação e na múltiplicidade de sentidos, formas, suportes e relações que a demanda do tempo atual permite e exige.

Palavras-chave: Fotografia; Arte contemporânea; Exposições.

\section{Abstract}

This article aims to think about photography inserted in the context of contemporary art, considering that, although contemporary photography has several biases, it is in the experimentation of artists and their current processes that photography definitely turn out from a common place, allocating itself into the non-specific, the fragmentation and the multiplicity of meanings, forms, supports and relations demanded for the present time. Keywords: Photography; Contemporary art; Exhibitions. 


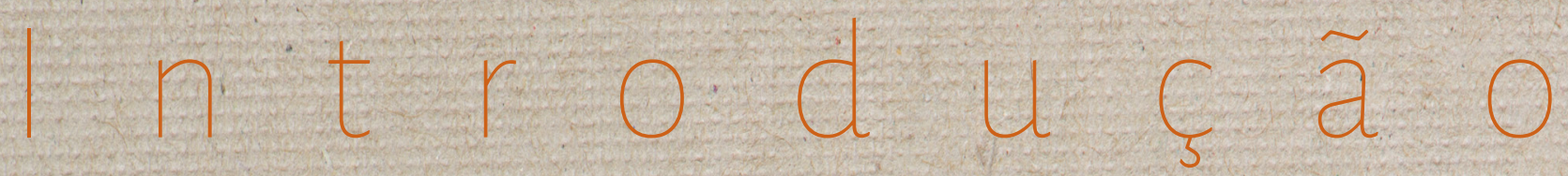

A fotografia não se destina sempre estritamente apenas às representações "terrestres e humanas" que sempre the foram reconhecidas. A foto também pode nos. fazer decolar. fazer o real oscilar em direção ao irrepresentável mais fundamental e mais experimental, pode nos revelar seu 'ser-anjo', esquecido ou oculto com demasiada frequência.

Philippe Dubois (7990, p. 268).

- incrivel como a fotografia e os debates em torno do seu lugar na escrita da história (da humanidade, da ciência e das artes) e dos papéis que ela ocupa nos discursos contemporâneos, não cessam de retornar. Por vezes, certas discussões, que em momentos consideraríamos superadas, voltam à tona com uma força surpreendente, tornando difícil se desvencilhar dos temas que acompanham o fotográfico desde suas origens. No campo da arte, vemos voltar a ganhar força nesse início do século XXI, por exemplo, especialmente em exposições de grandes e importantes museus de fotografia e de arte moderna/contemporânea, a pergunta que acompanha o fotográfico desde seus primórdios: o que é a fotografia?

Recentemente, duas grandes instituições museológicas, o Iñternational Cen- ter of Photography, em Nova lorque, e o CentreGeorgesPompidou, em Paris, apresentaram ao público exposições que carregavam tal pergunta,propondo, por diferentes caminhos, o debate e o pensamento sobre a natureza da fotografia hoje. Refiro-me às mostras What is a photograph?(2014), com curadoria de Carol Squiers, e Qu'est-ce que la photographie? (2015), com curadoria de Karolina Ziębińska-Lewandowska e Clément Chéroux. Essas exposições nos ajudam a pensar em como, de mais a mais, o fotográfico se inscreve na história e, de certa forma, fundamenta boa parte da escrita da história da arte contemporânea, a partir dos processos e estratégias expressivas que questionam o meio, desprezam conservadorismos e enxertam novas formas de uso da fotografia dentro do discurso artístico, seja enquanto ferra- 
menta de produção ou enquanto essência e fundamento das obras.

\section{What is a photograph?}

A primeira propõe o olhar principalmente para a questão da virada digital, mas também para a produção de artistas que desafiam o sistema maquínico e social estabelecido para a fotografia, a retirando de um lugar comum de registro e documentação. Suportes diferenciados, intervenção no suporte seja ele papel ou não -, interferência no processo de feitura (revelação/impressão da imagem), associação a outras especificidades expressivas - pintura, escultura, por exemplo - ou a objetos e instalações, enfim, um sem número de caminhos que a criatividade dos artistas nos permite, enquanto espectadores, percorrer.

Segundo Carol Squiers (2014, p. 9-10),

esses artistas reinventam e redefinem o papel da luz, da cor, da composição, da materialidade e dos temas tratados na ("arte da") fotografia e, confrontados com uma inesperada revolução fotográfica na era do digital, reexaminam criativamente a fotografia analógica, fazendo com que ambas: fotografia digital e analógica, a partir de criações híbridas fluam juntas, em seus processos criativos. ${ }^{1}$

Dentre as obras apresentadas, majoritariamente recentes, temos os trabalhos de Lucas Samaras, produções mais antigas, datadas do final da década de 1960 até meados da década de 1970 (Imagens 7 a 3).

Samaras é um dos primeiros artistas a fazer uso da polaroide de maneira não documental e vernacular, inserindo a câmera, e seus processos, no discurso de sua produção que já vinha sendo construída em suportes diversos tais como o escultural, o pictórico e o performático.

A princípio, usando uma Polaroide 360, o artista interferia na superfície da imagem produzindo pontos e marcas de tinta que encobriam detalhes mundanos e banais e as áreas fora de foco. Essas marcas repetiam ou se assemelhavam muitas vezes, aos elementos que compunham seus objetos esculturais: cacos de vidro, lâminas de barbear, penas, contas...

1 Tradução livre da autora a partir do original em inglês. 
Imagem 1 - Box 68 [aberta e fechada], de Lucas Samaras (1968).
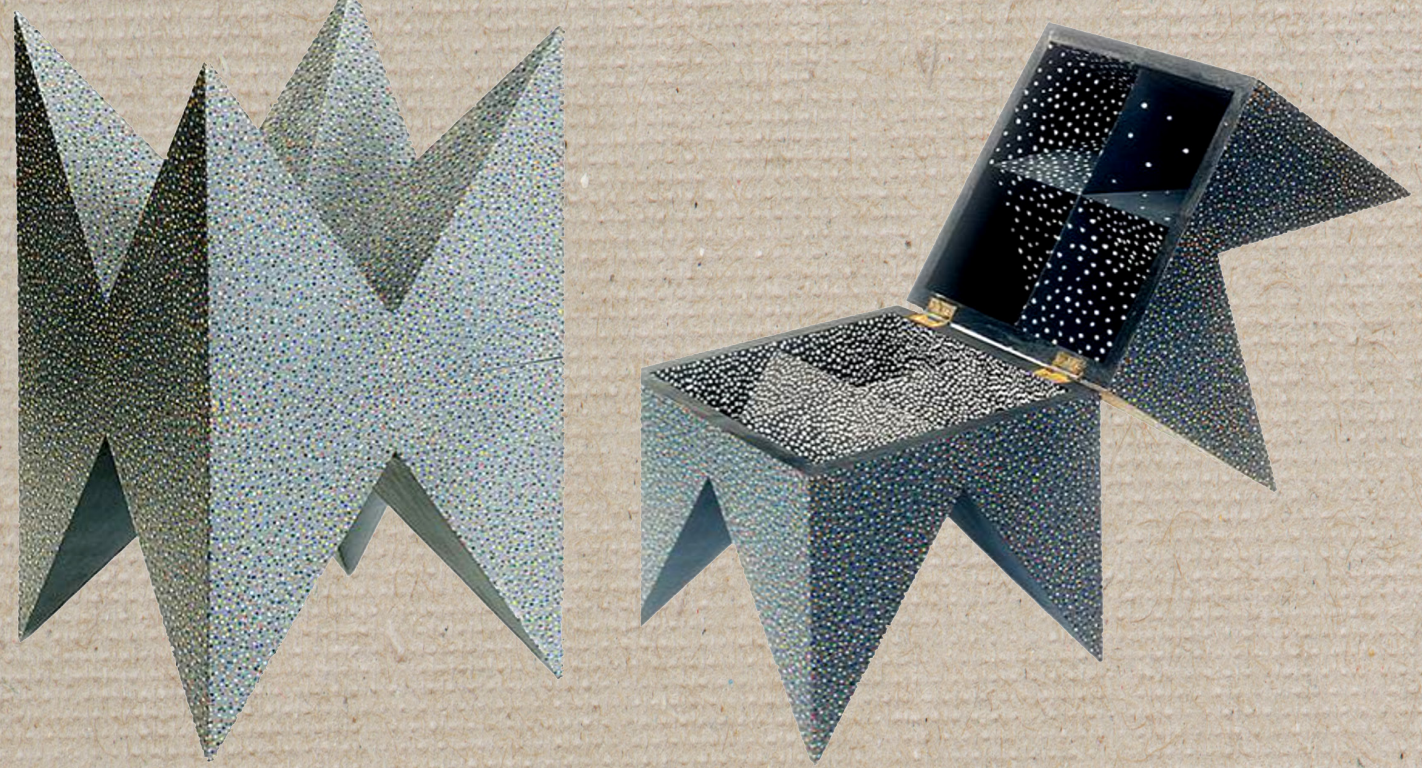

Fonte: National Gallery of Australia (2016)

Imagem 2 - Auto Polaroid, de Lucas Samaras (1969-1971).

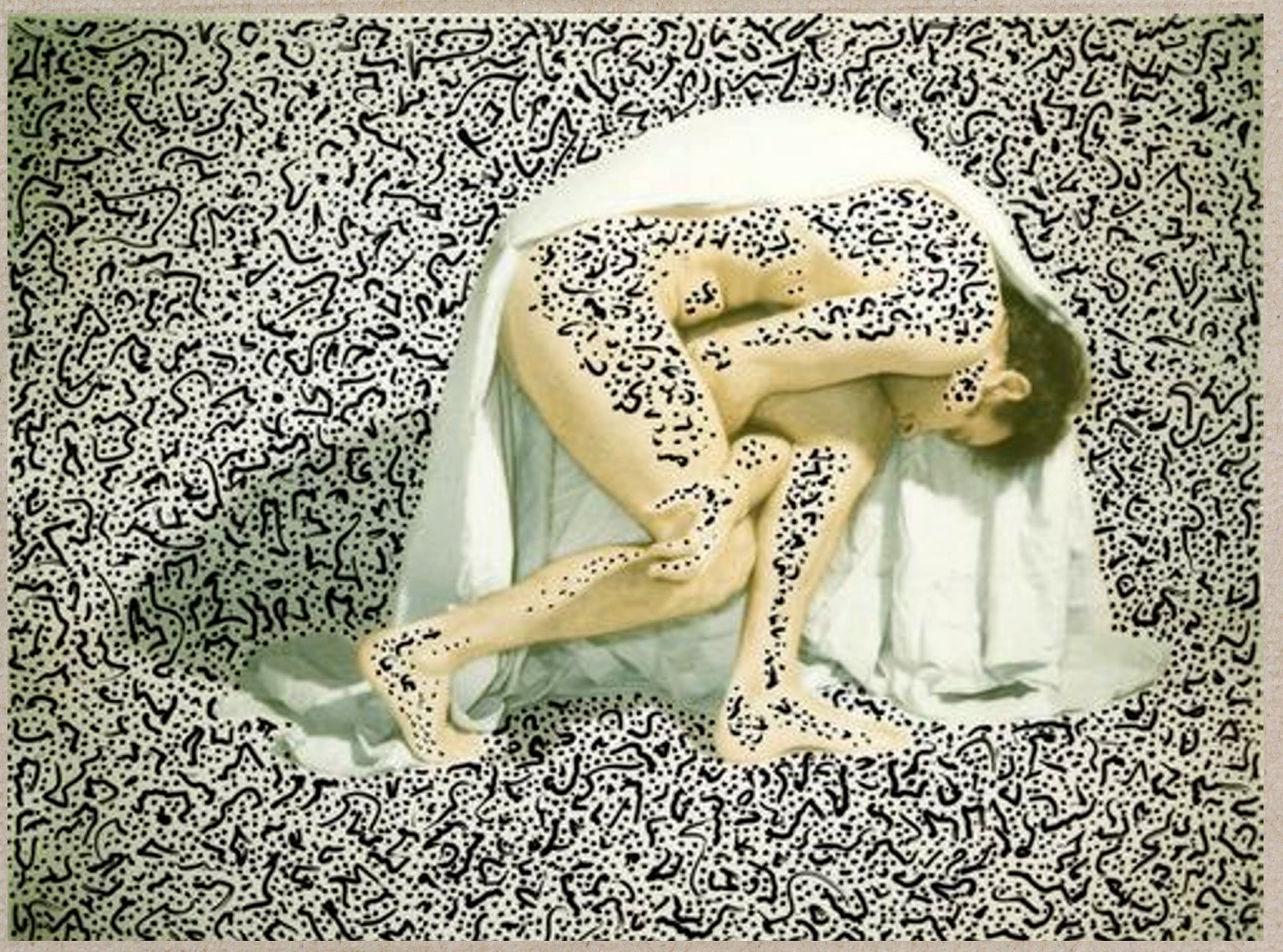

Fonte: National Gallery of Australia (2016). 
Entretanto, em 7973 a Polaroid Corporation disponibiliza para Samaras seu novo modelo, a Polaroide $S X-70$ cuja emulsão permanecia maleável enquanto a imagem se formava, o que Ihe permitiu manipular o processo de feitura dessa imagem através da pressão contra a pele plástica que recobria o suporte. Dessa maneira, seu próprio "corpo fotográfico" se tornava moldável e transformável, num processo criativo que tinha um resultado carregado de subjetividades e significações próprias do artista, que afirma que as fotografias remetem aos seus medos, narcisismos e memórias. Segundo Samaras (apud SQUIERS, 2014, p. 14), a Polaroid foi uma alternativa ao happe-

Imagem 3 - Photo-Transformation, de Lucas Samaras (1973-76).

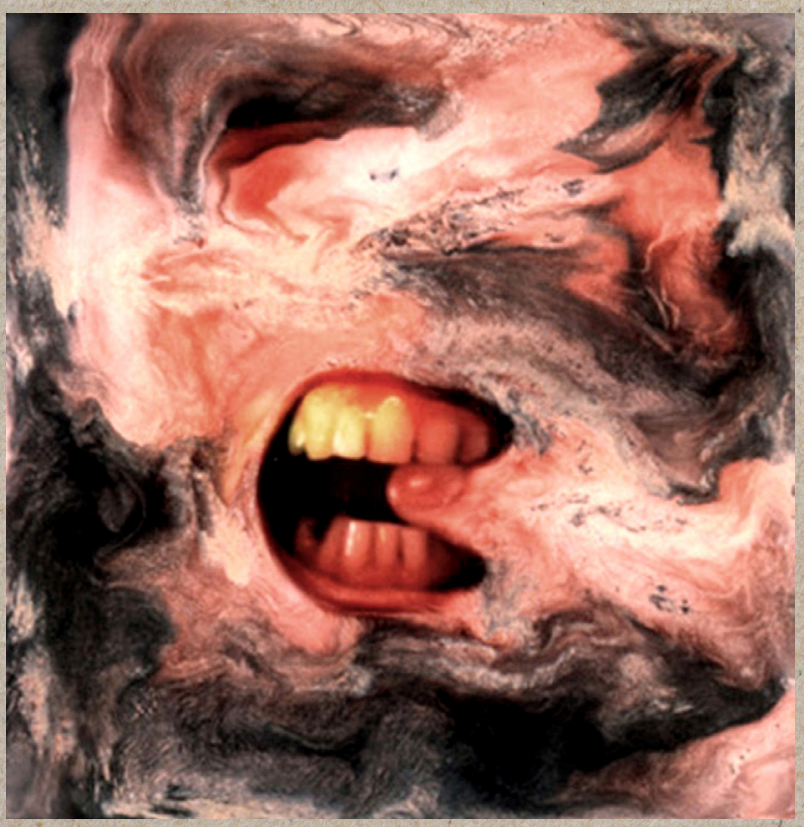

Fonte: Squiers (2014, p. 190). ning, em moda na época: "ela me permite desenvolver meu happening num tempo próprio e apresentá-lo quando, pronto, sem riscos de erro"2.

Outro destaque, dentre artistas mais consolidados no campo da pintura, é Gerhard Richter, que tem apresentadas suas fotografias vernaculares pintadas (Imagens 4 e 5). Pinturas estas que, porvezes, propõem a relação técnica com os óleos sobre tela do artista, por outras se caracteriza por pinceladas grossas, que constroem camadas densas de abstração no figurativo familiar ou de paisagens.

Imagem 4-16.03.03, de Gerhard Richter (2003).

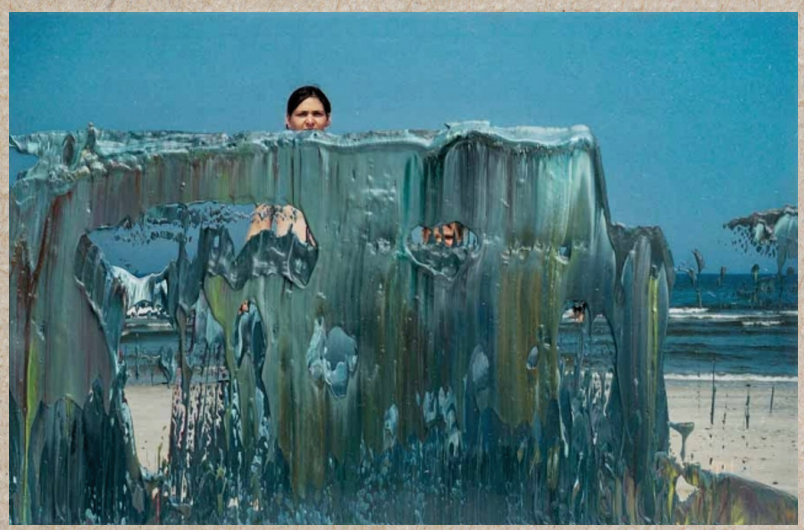

Fonte: Squiers (2014, p: 164).

O ritmo das obras se dá no diálogo ente fotografia e pintura, a partir das sobrecamadas e das transparências/ opacidades que o artista cria na imagem. O processo do Richter, mais co-

2 Tradução livre da autora. 
nhecido até então por suas pinturas hiper-realistas, é desenvolvido a partir de um incidente no atelier, durante a pintura de um quadro. Ao perceber o gotejamento da tinta na imagem fotográfica em que se baseava para produzir uma de suas telas, ele decide interferir intencionalmente no álbum familiar e de viagens. E, em conjunto com a produção das telas, continuou desenvolvendo esse processo de pintura sobre suporte fotográfico por mais de duas décadas (SQUIERS, 2014, p. 18-19).

Imagem 5 - Firenze (16/99), de Gerhard Richter (2000).

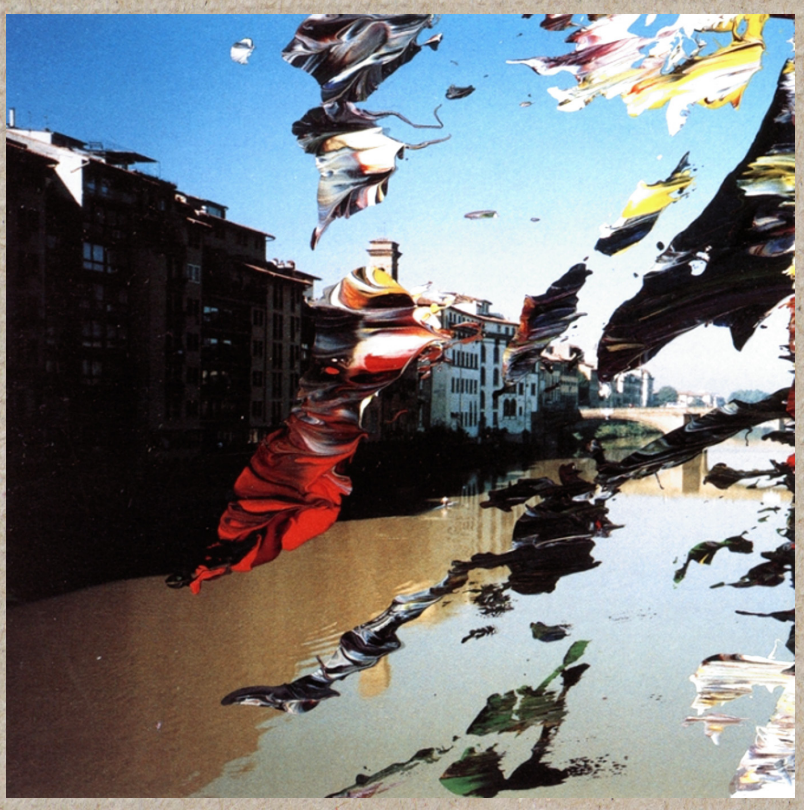

Fonte: Squiers (2014, p. 168).

Sigmar Polke, também presente na mostra, apresenta fotografias produzidas especialmente a partir do total jogo com as regras do meio (Imagem
6). Seu trabalho se desenvolve em especial a partir do uso do erro: exagero ou troca de químicas na revelação, uso de uma iluminação diferente durante o processo de produção da cópia positiva, movimentos inesperados de câmeras durante as tomadas, reposicionamento do filme na câmera etc. Uma verdadeira "enciclopédia de erros" (HAMBOURC apud SQUIERS, 2014, p. 16), que por vezes tem as imagens ainda trabalhadas pelo artista, com tintas sobre o negativo ou sobre o próprio papel fotográfico (originalmente, Polke era pintor), resultando num conjunto variado e sem estilo/técnica definidos, extremamente originais.

Imagem 6-Sem título, de Sigmar Polke (1970).

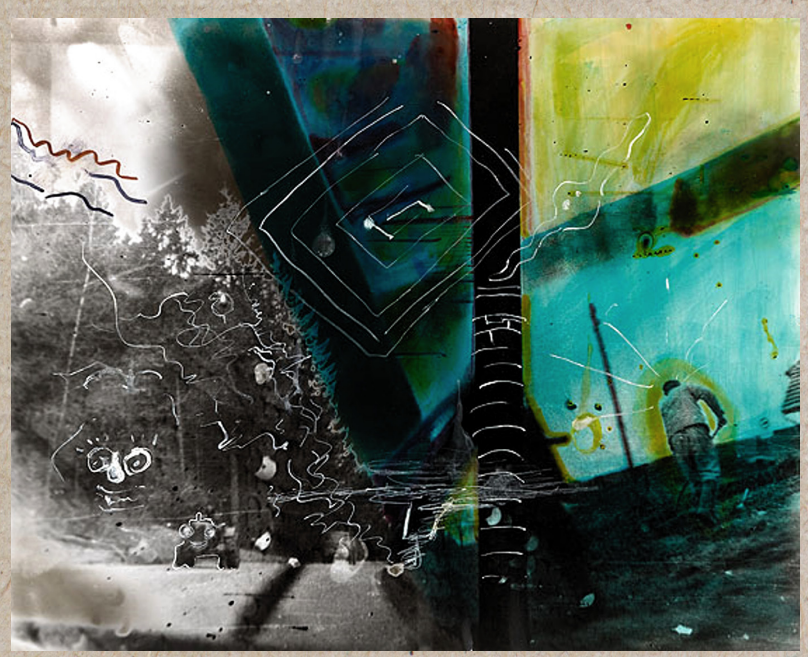

Fonte: Squiers (2014, p. 138)

Artistas mais recentes aparecem também com grande força na exposição. É o caso, por exemplo, de Marlo Pascual, 
norte americana que produz obras a partir de arquivos fotográficos - às vezes próprios, mas majoritariamente apropriados - e hibridizados com objetos e elementos cotidianos (velas, bancos de madeira, pedras, plantas etc.), ou submetidos a intervenções digitais ou manuais da artista, ganhando quase sempre um toque tridimensional e escultórico (Imagem 7). São obras que não se alocam especificamente, mas transitam no campo da fotografia e da escultura, seja pela força de um objeto concreto presente, seja pelo alcance tridimensional da materialidade fotográfica, na maioria das vezes, impressões cromogênicas e acrílico.

Outro destaque na exposição é Mathew Brandt com sua série de lagos e reservatórios, na qual ele afunda as impressões fotográficas nas águas que aparecem representadas na fotografia (Imagem 8). O resultado, em função dos papeis que utiliza, das cores do próprio ambiente ou de sua saturação, e do tempo de imersão da imagem na água, varia muito, de uma imagem a outra, tendo um resultado final, enquanto série, que apresenta ao espectador fotografias que vão desde uma paisagem figurativa emoldurada pela ação da água nos cantos externos do papel fotográfico, até imagens quase abstratas, visto que a camada criada pela atuação da água causa um quase completo desaparecimento do figurativo paisagístico.

Letha Wilson aparece na exposição com suas grandes impressões em alumínio e
Imagem 7 - Sem título, de Marlo Pascual (2017).

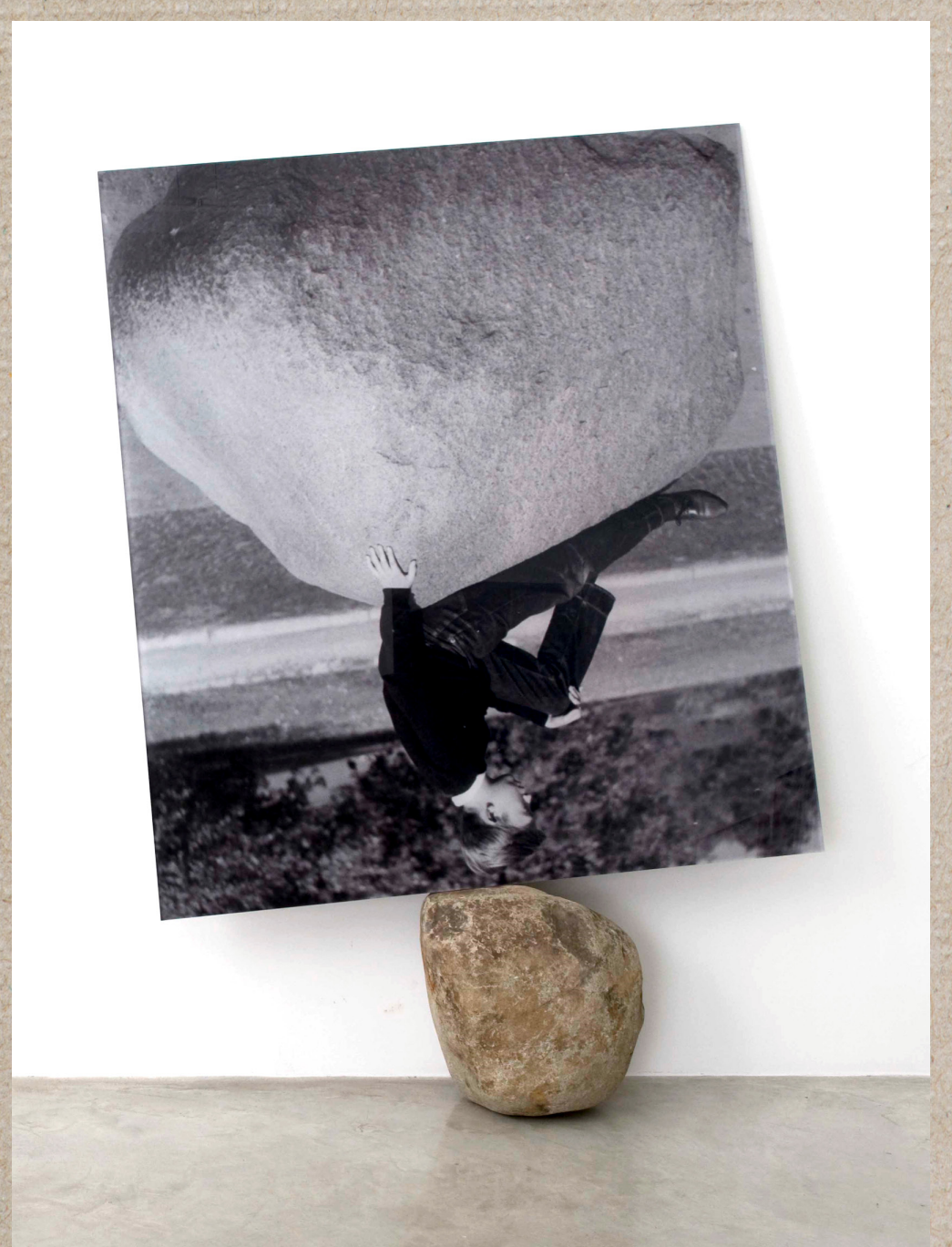

Fonte: Squiers (2014, p. 132). 


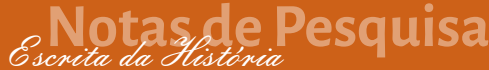

Imagem 8 - Mary's Lake, MT 4, de Matthew Brandt (2012)

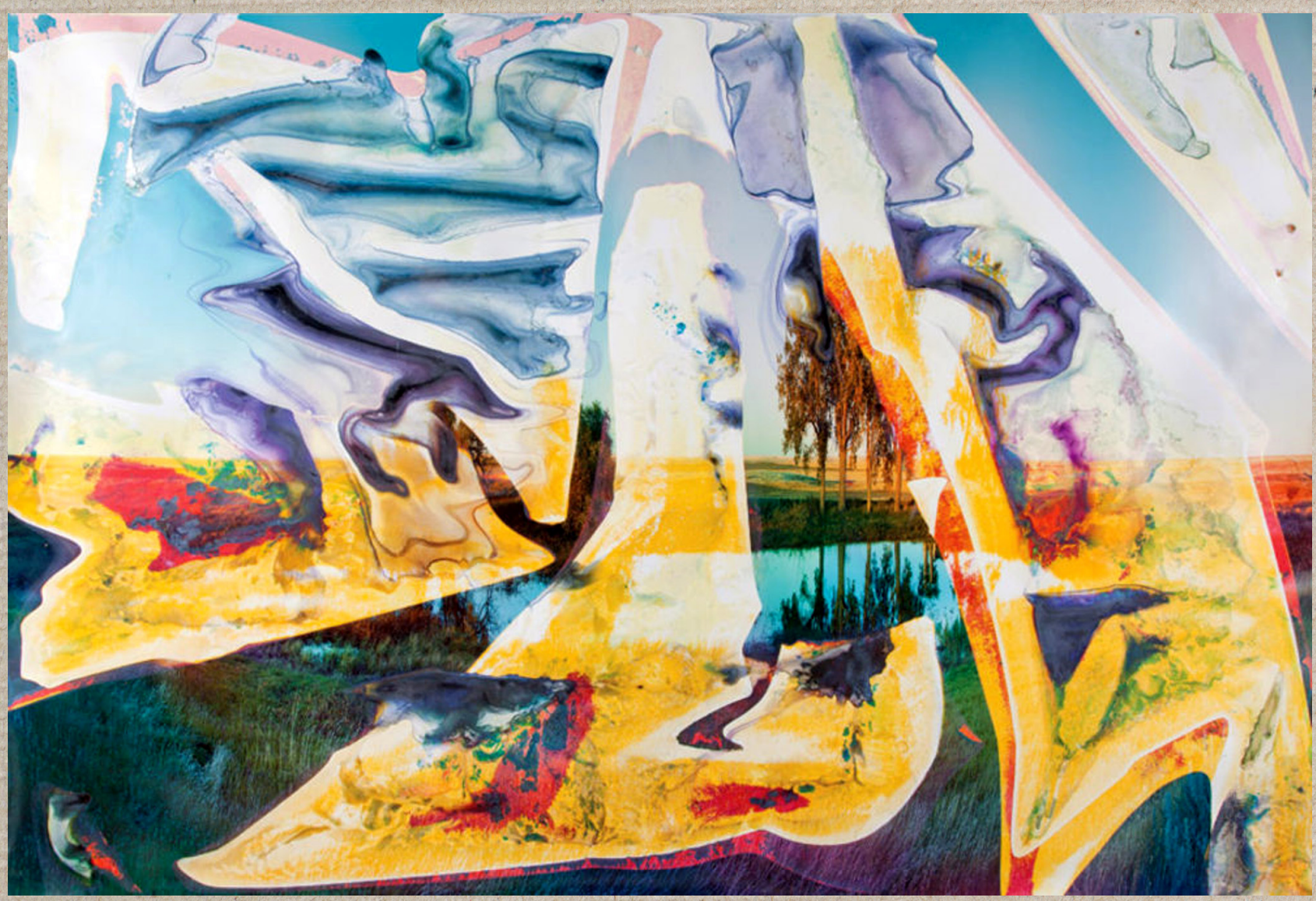

Fonte: Squiers (2014, p. 82-83)

com uma artesania própria na materialidade - alumínio, madeira, concreto e papel fotográfico - produz obras a partir de recortes, colagens, construções de instalações, que trazem novamente 0 diálogo entre fotografia e escultura ou entre bidimensional e tridimensional (Imagem 9).

Junto com estes, muitos outros artistas (Marco Breuer, Liz Deschenes, Adam Fuss, Owen Kydd, Floris Neusüss, Eileen Quinlan, Jon Rafman, Mariah Robertson, Alisson Rossiter,
Imagem 9-Colorado Purple, de Letha Wilson (2012).

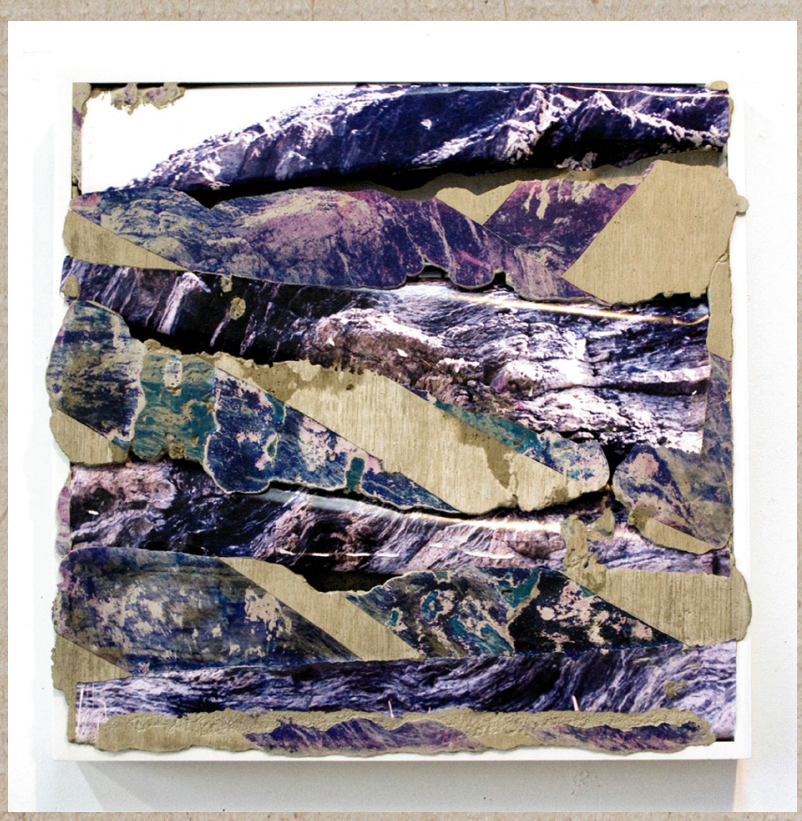

Fonte: Squiers (2014, p. 248) 
David Benjamin Sherry, Travess Smalley, Kate Steciw, James Welling, Artie Vierkant e Christopher Willians), por diferentes caminhos e modalidades expressivas de um trabalho que tem como parte, ou essência, a fotografia em suas variadas formas técnicas e processuais, formam um conjunto amplo e diverso de práticas e processos contemporâneos que têm como cerne a fragmentação, as camadas e a criação de mundos particulares, especialmente a partir do diálogo, não só entre especificidades e técnicas artísticas, mas entre a fotografia analógica e digital, e destas com as artesanias e interferências subjetivas dos artistas.

\section{Qu'est-ce que la photographie?}

Já na segunda exposição que me proponho a analisar no presente artigo, ou seja Qu'est-ce que la photographie?. temos principalmente obras que antecedem à denominada virada digital, mas que da mesma forma, respondem à célebre questão "O que é a fotografia?" a partir de vários lugares, ações e pontos de vistas. Trata-se de uma exposição aparentemente didática, mas que, na realidade, tem como objetivo ser uma das ironias mais elaboradas que já se viu sobre o assunto.

Clément Cheroux, ex-curador do Ca- binet de Photographie do Centro Georges Pompidou e atualmente curador do MoMA de San Francisco, afirma que a exposição, a partir de obras, artistas, lugares, estratégias e pontos de vista e de pesquisa diversos, tem por objetivo provar que nunca houve, ou haverá, uma resposta fechada para aqueles que se deleitam com explicações ipsis litteris sobre questões de um mundo onde o unívoco não tem espaço, que é o mundo da fotografia, isto é, a resposta para a pergunta $O$ que é a fotografia? não tem resposta de fato; ou melhor, tem tantas respostas quanto a capacidade de criação e produção dos artistas no âmbito do fotográfico ${ }^{3}$.

Na exposição, bem como no catálogo, as obras são dispostas em blocos temáticos que englobam de três a cinco subtemas, alocando uma obra em cada um destes sub-blocos. A exceção é Ugo Mulas, que ocupa sozinho o último deles, "Des vérifications", com uma série hómônima de fotografias em que analisa e verifica a fotografia a partir de suas características temporais, e também a partir daquilo que o maquínico e o mecânico conseguem captar no instante fotográfico.

De acordo com Chéroux (2015, p. 140), ao realizar essas fotografias, que têm

3 Em entrevista concedida à autora em 27 de setembro de 2016, em Paris. 
por tema a fotografia em si, e buscam identificar seus elementos constitutivo's e seu valor, Mulas consegue obter a resposta mais perspicaz que um fotógrafo já pôde dar à questão.

A seguir, arrolo os outros blocos da exposição e seus respectivos subtemas ${ }^{4}$, para que o leitor possa melhor perceber esse percurso proposto pelos curadores da exposição.

1) Bloco "As vontades", com os seguintes sub-blocos:

a) Desejo de Ver:

Imagem 10 - No Teatro, de Paul Citroen (1930).

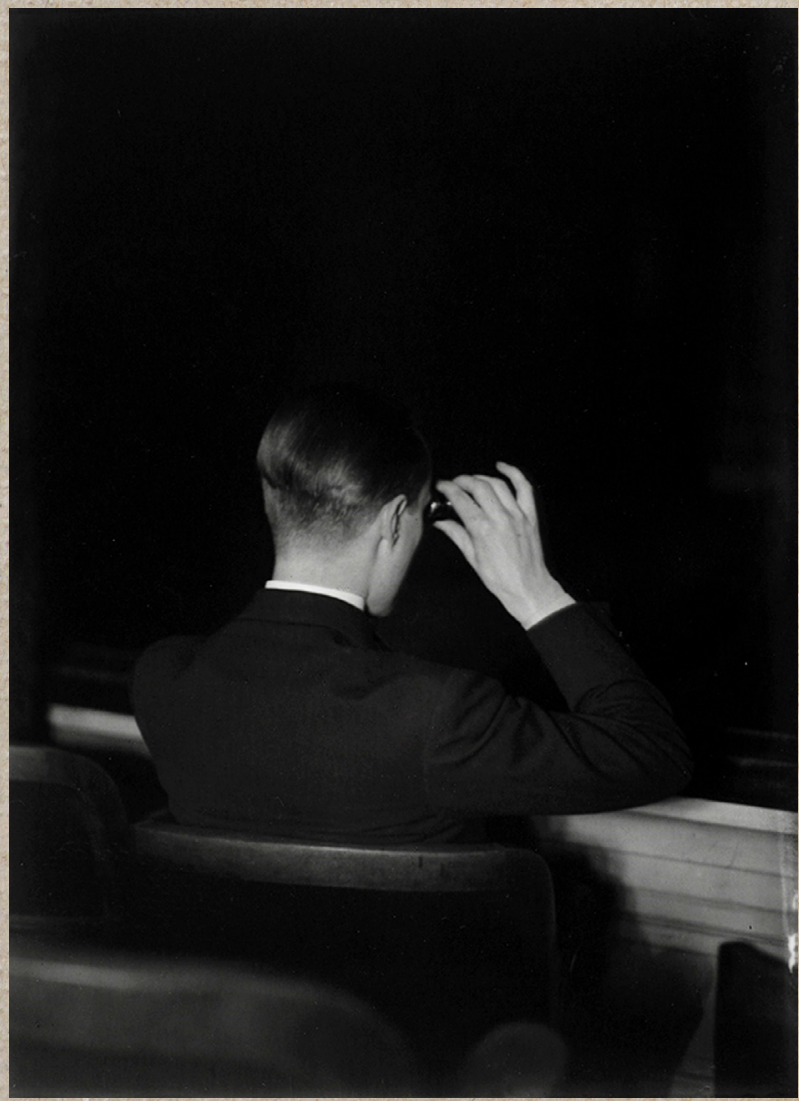

Fonte: Cheroux e Ziebinska-Lewandowska (2015, p. 35).

4 Tradução livre do francês. b) Atração pela luz: Brassai é apresentado no sub-bloco com duas imagens a seguir:

Imagem 11 - Borboleta na Lâmpada, de Brassaï (1934).

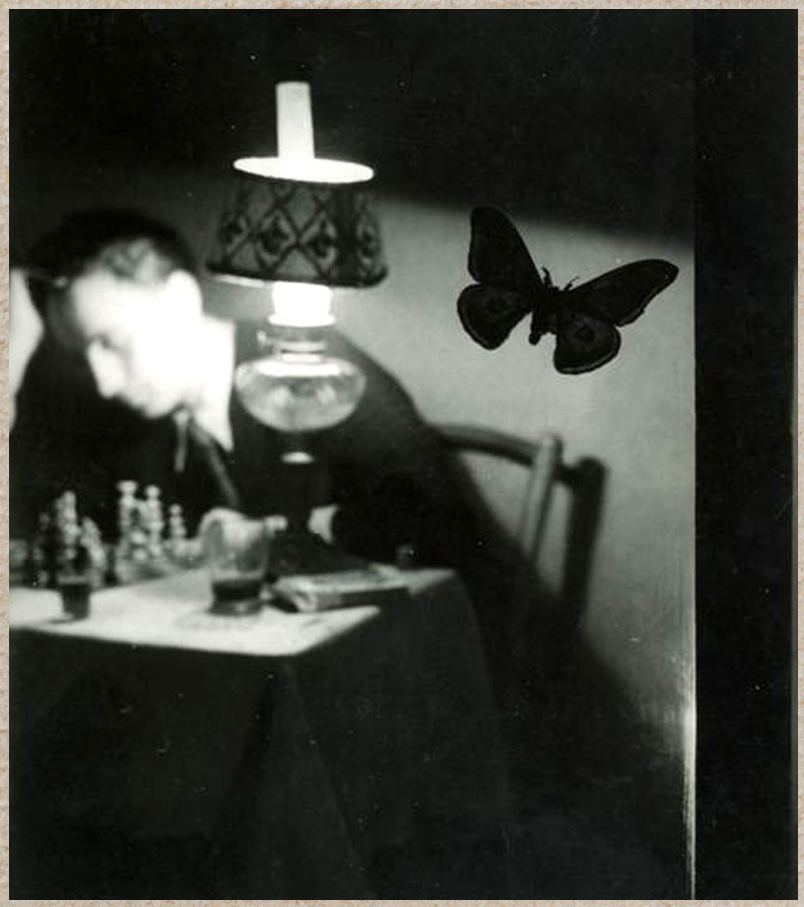

Fonte: Cheroux e Ziebinska-Lewandowska (2015, p. 37).

c) Teatro de sombras:

Imagem 12-Autorretrato, de André Kertésż (1927).

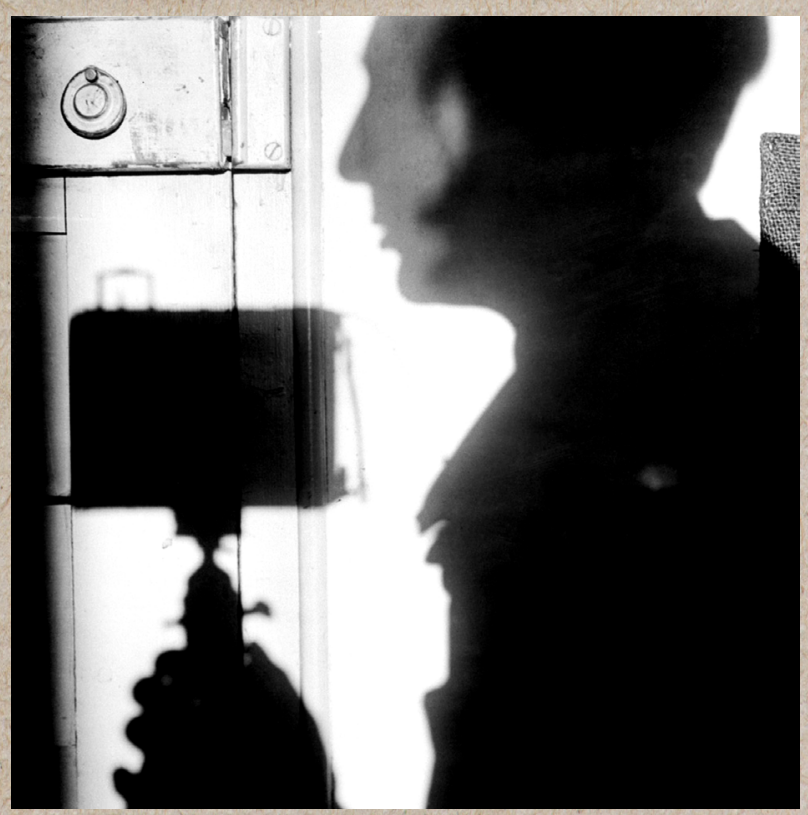

Fonte: Cheroux e Ziebinska-Lewandowska (2015, p. 41). 
d) Olhar:

Imagem 13 - Olho na Janela, de Nathan Lerner (1943).

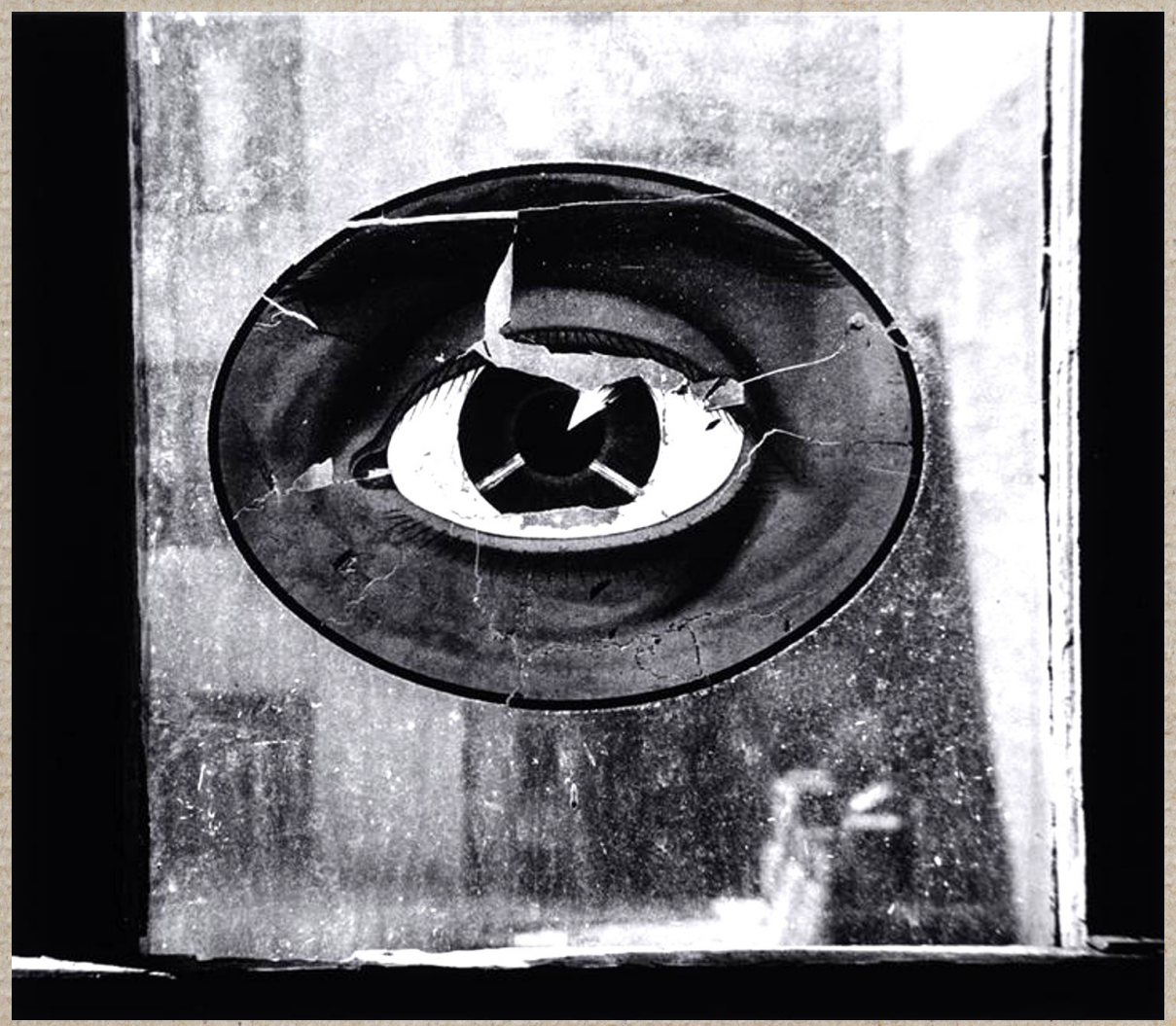

Fonte: Cheroux e Ziebinska-Lewandowska $(2015$, p. 41).

2) Bloco "Os materiais", com os sub-blocos:

a) Gelatina:

Imagem 14 - Fotografia Gelatina 40, de James Welling (1984).

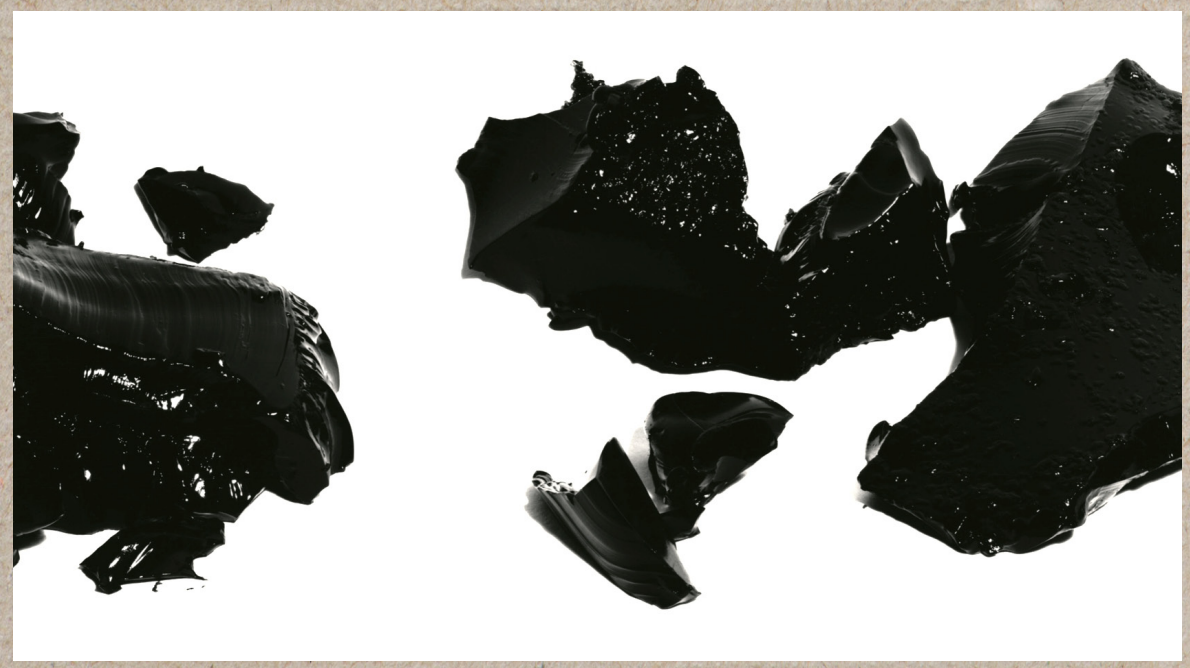

Fonte: Cheroux e Ziebinska-Lewandowska (2015, p. 47). 


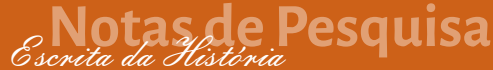

b) Crãos de prata:

Imagem 15 - Quatro Fotogramas de Luz, de Ciulio Paolini (1969).
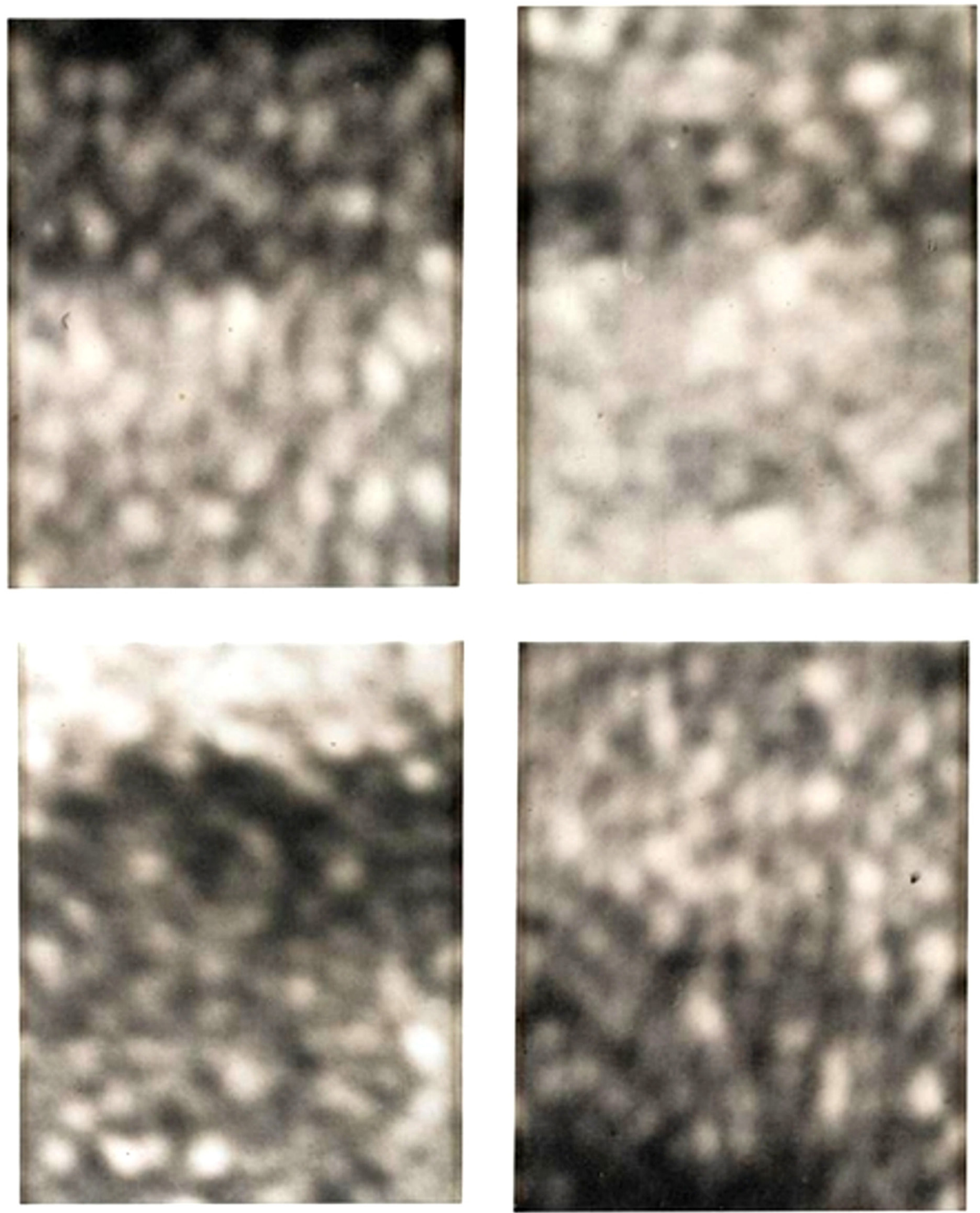

Fonte: Cheroux e Ziebinska-Lewandowska (2015, p. 51-54). 


\section{c) Promessas: .}

Imagem 16 - Caixa de Negativos, de Man Ray (1957).

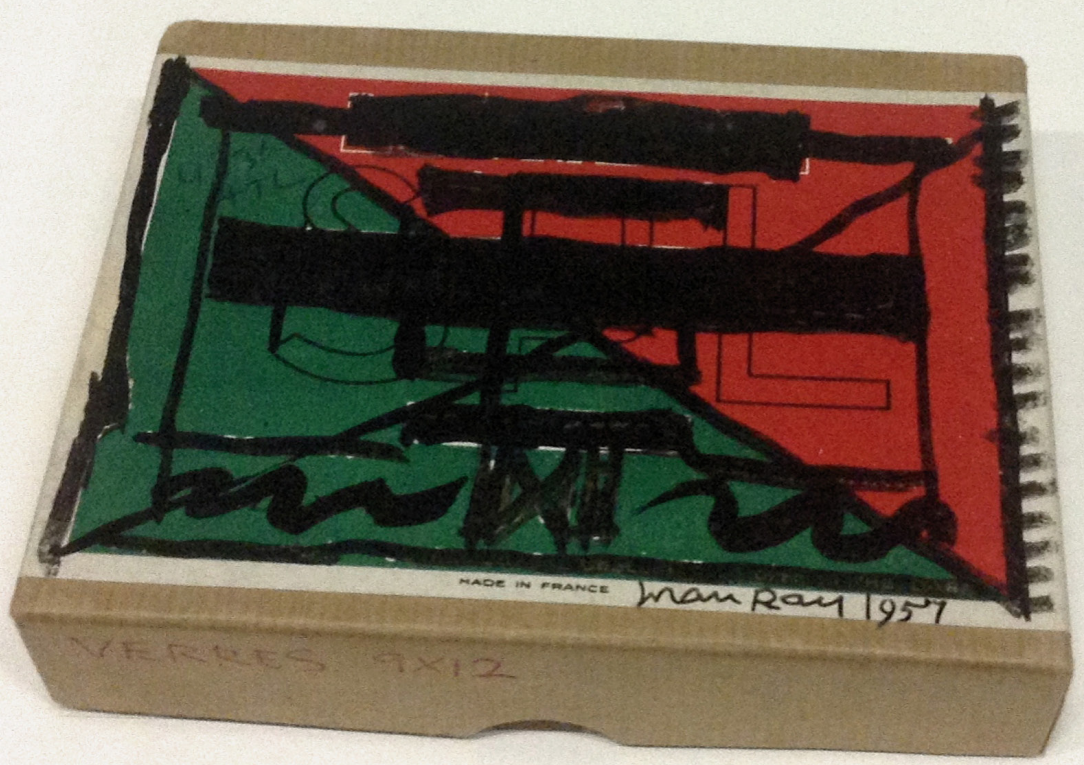

Fonte: Cheroux e Ziebinska-Lewandowska (2015, p. 59).

d) Superfície Sensível:

Imagem 17 -Sem título, de Joseph Beuys (7963).

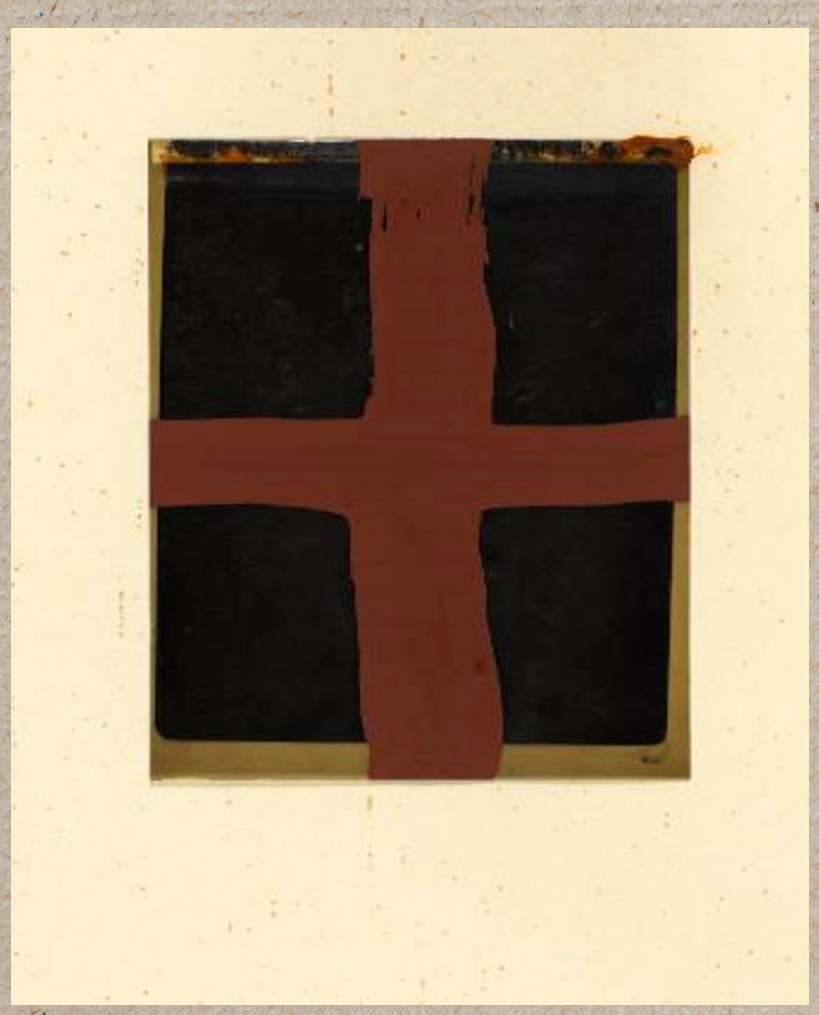

Fonte: Cheroux e Ziebinska-Lewandowska (2015, p. 61). 
3) Bloco "Princípios", com os sub-blocos:

a) Insolação:

Imagem 18 - Posição de Leitura para uma' Queimadura de Segundo Grau, de Denis Oppenheim (1970).

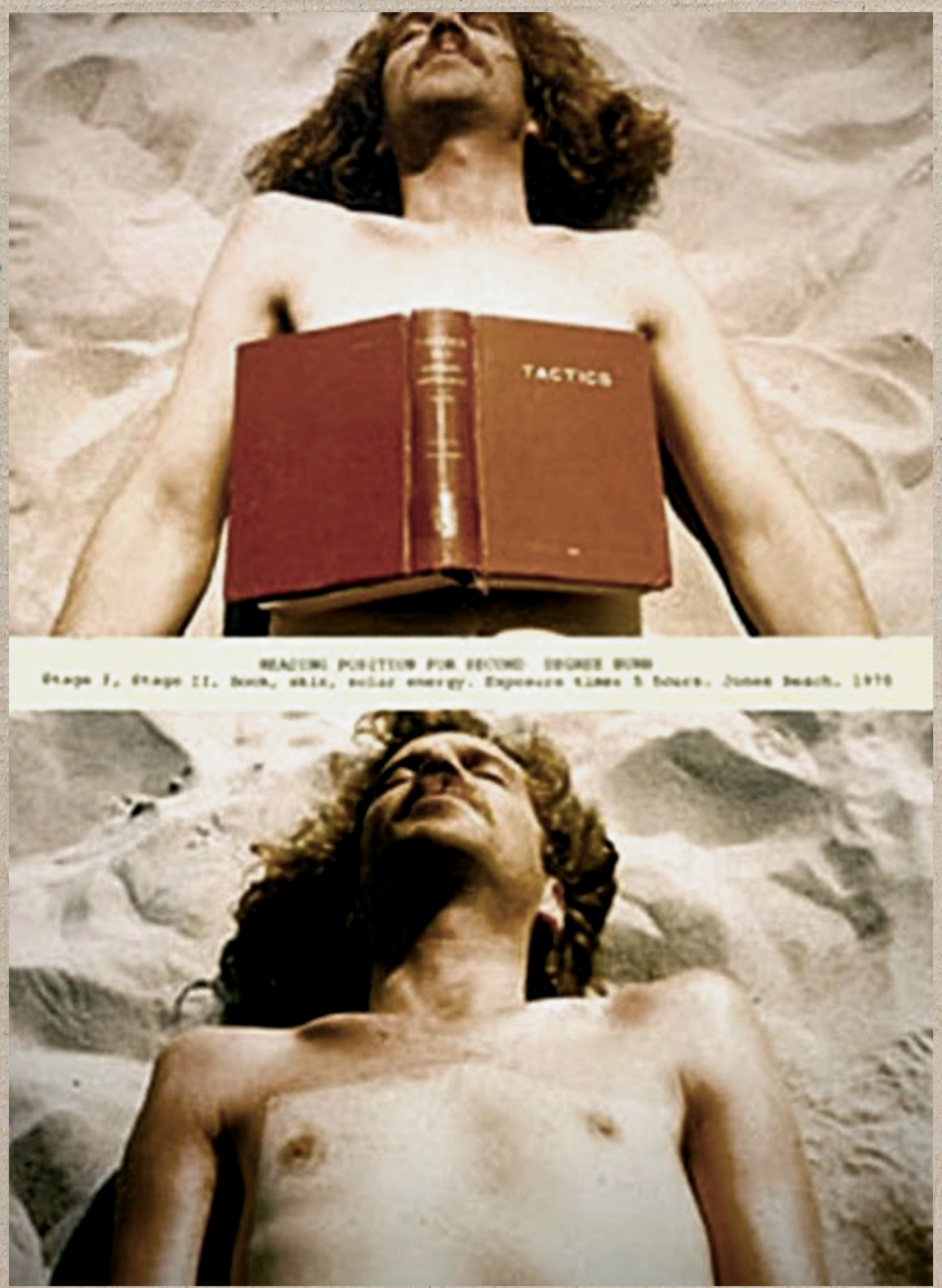

Fonte: Cheroux Ziebinska-Lewandowska (2015, p. 65). 
b) Câmera Obscura:

Imagem 19-Câmera Obscura Imagem de Boston, de Abelardo Morel (1998).

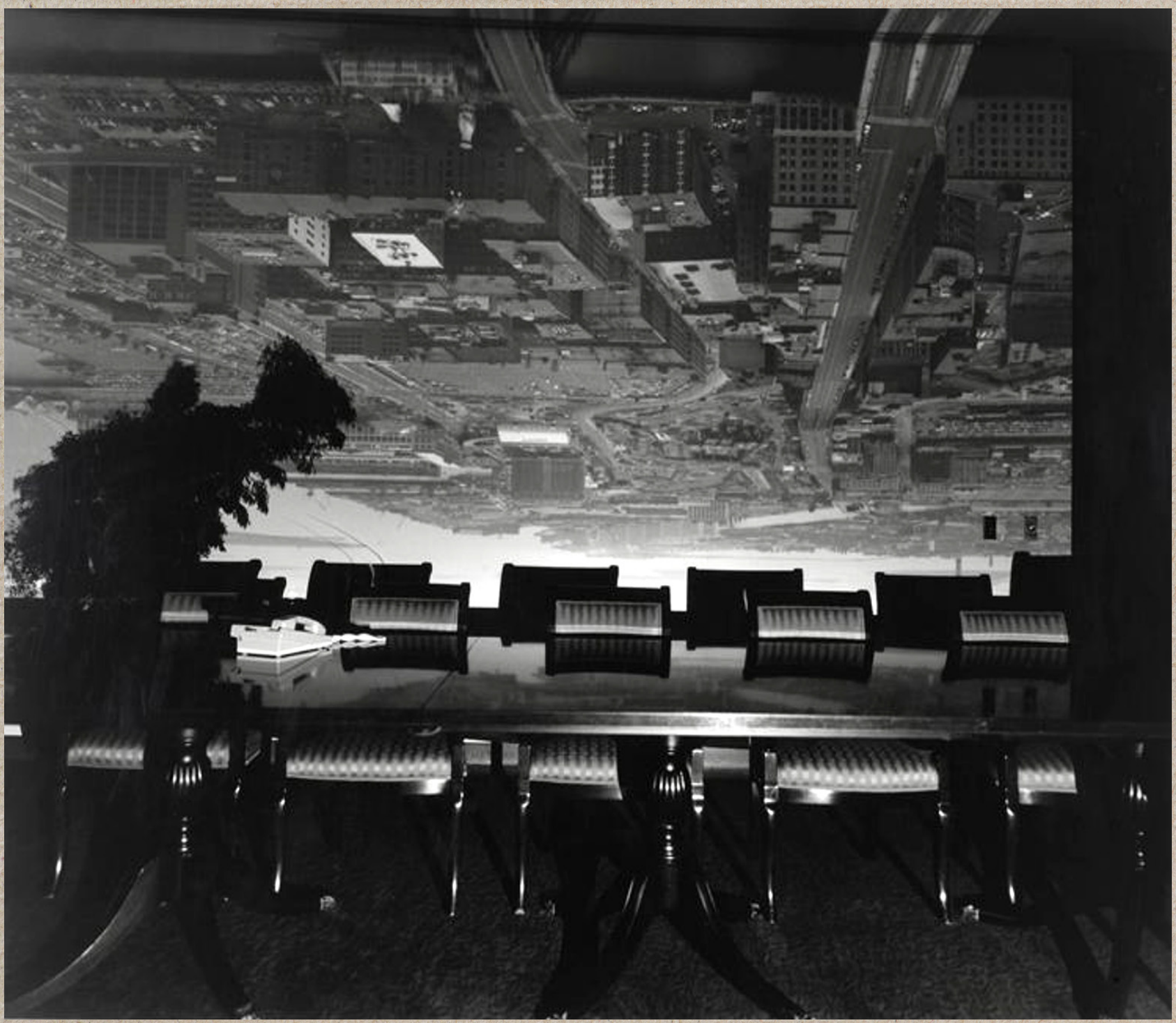

Fonte: Cheroux e Ziebinska-Lewandowska (2015, p. 67). 
c) Fixação:

Imagem 20-O caminhante [tríptico], de Patrick Tosani (1982-83).
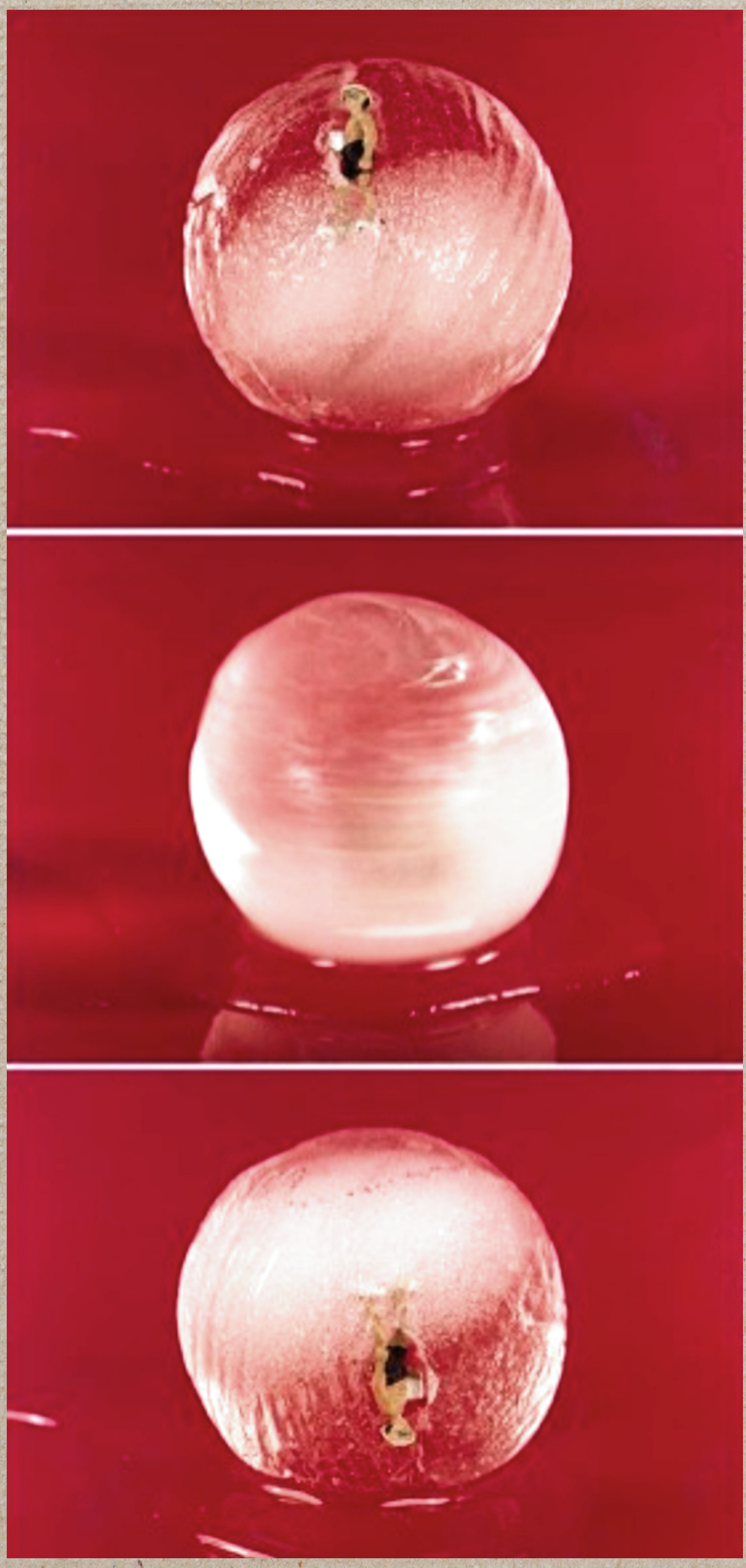

Fonte: Cheroux e Ziebinska-Lewandowska (2015, p. 69-71). 
4) Bloco "Práxis", com os seguintes sub-blocos:

a) Ponto de vista:

Imagem 21 - 5 de abril, Gizé, Egito, de Denis Roche (1987).

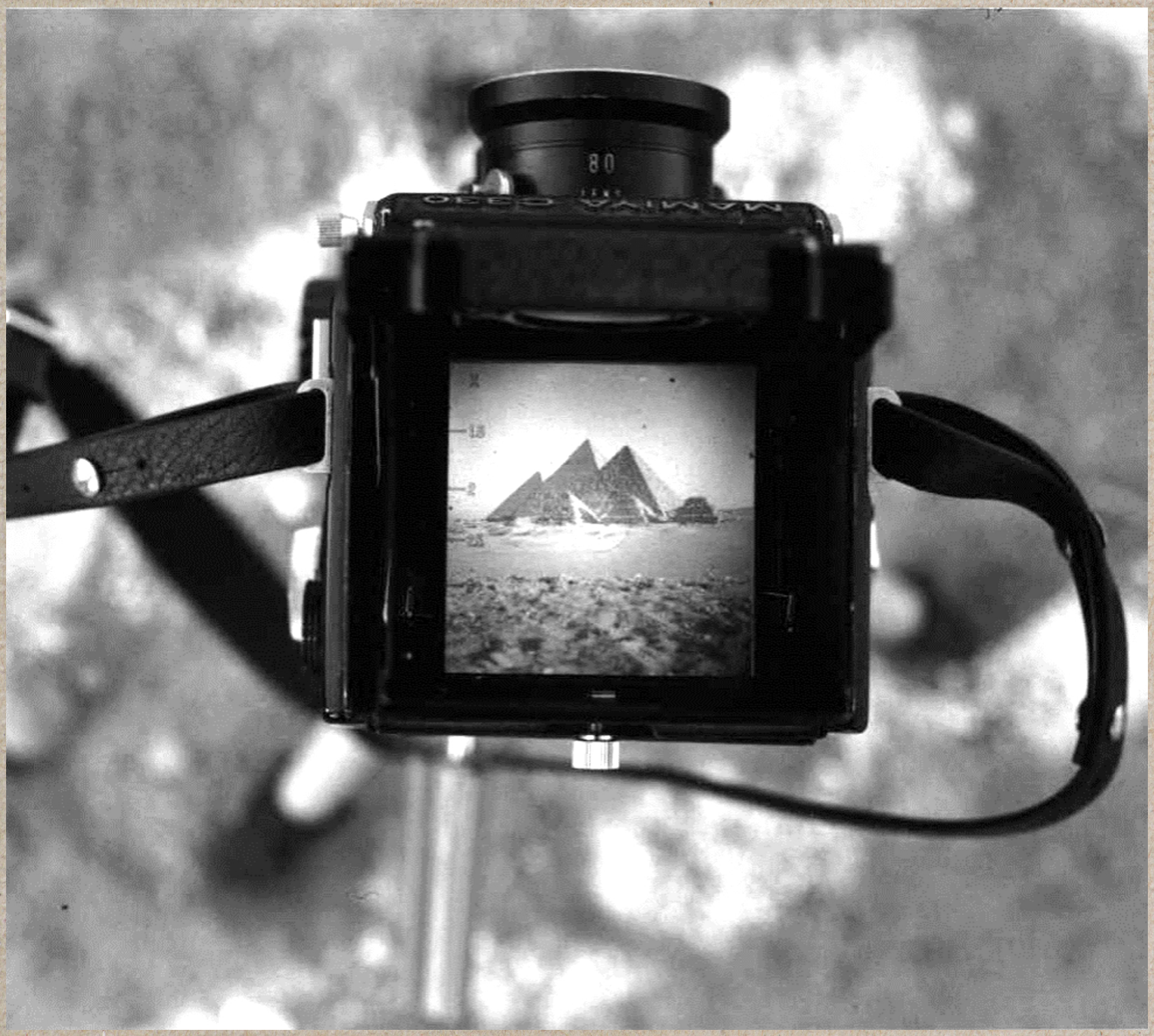

Fonte: Cheroux e Ziebinska-Lewandowska (2015, p. 75). 
b) Enquadramento:

Imagem 22 - Saqueado/Escavado/Seco/ Preparado, de John Hilliard (1975).
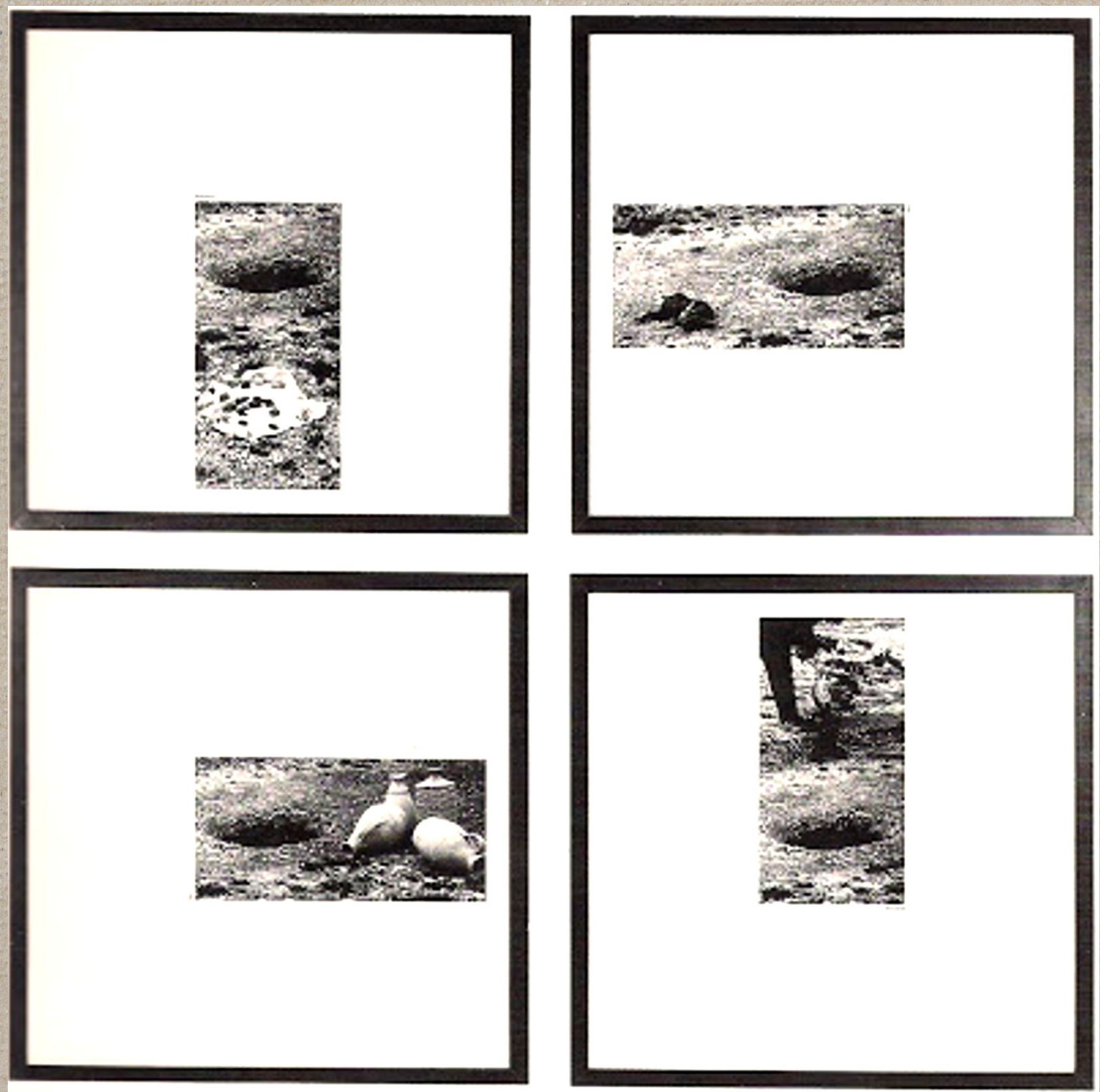

Fonte: Cheroux e Ziebinska-Lewandowska (2015, p. 77). 
c) Profundidade :

Imagem 23 - Zona Óptica, de Jósef Robakowski (1975).

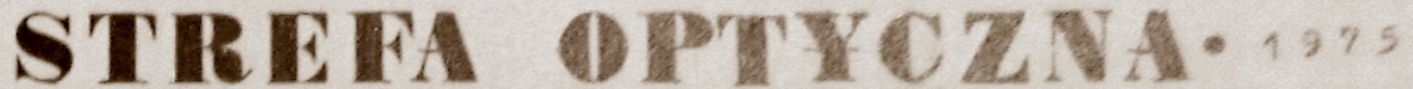

66

46

58
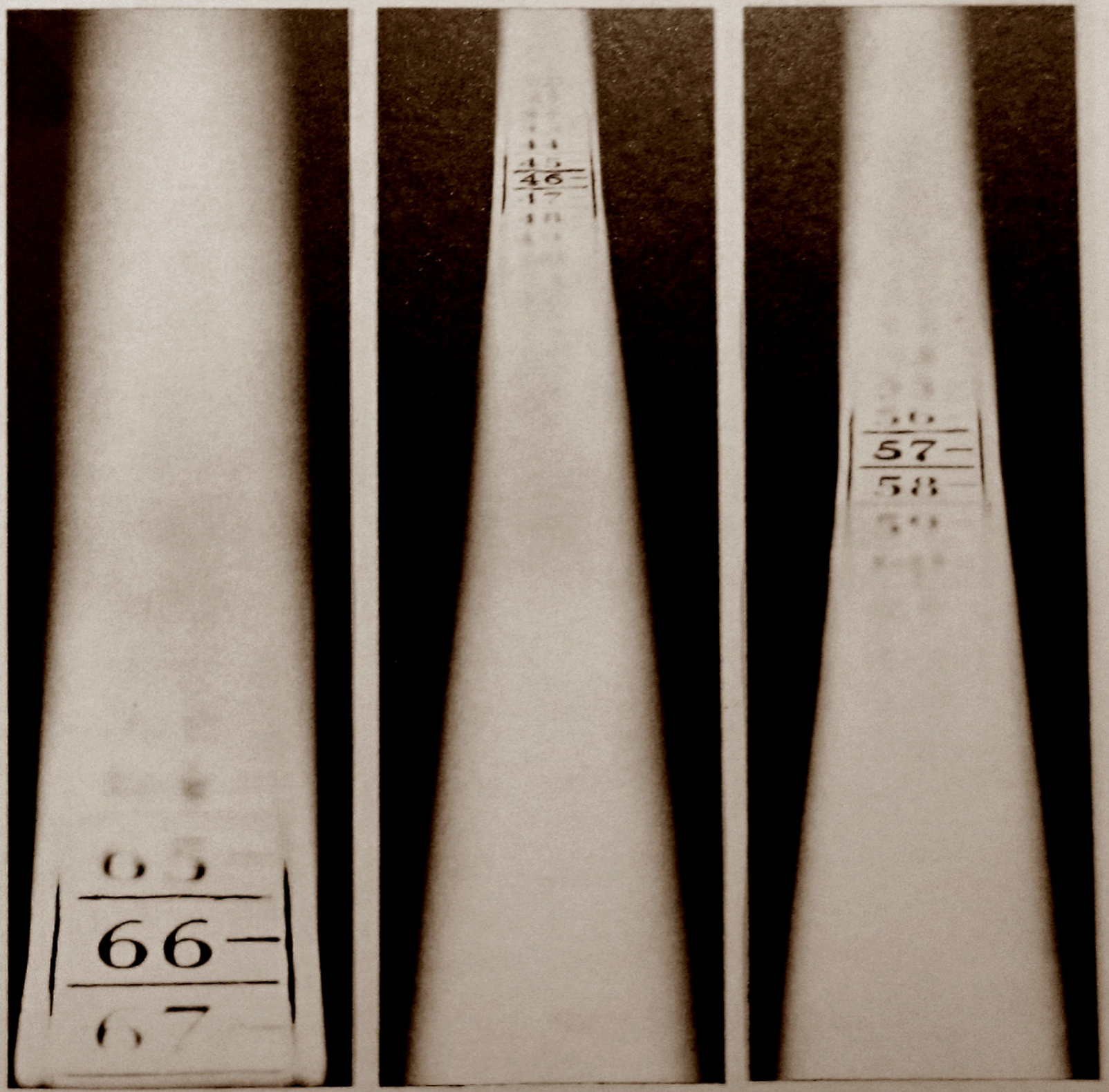

Fonte: Cheroux e Ziebinska-Lewandowska (2015, p. 79). 
d) Automatismo:

Imagem 24 - Passagem entre Duas Tomadas, de Man Ray (1937).

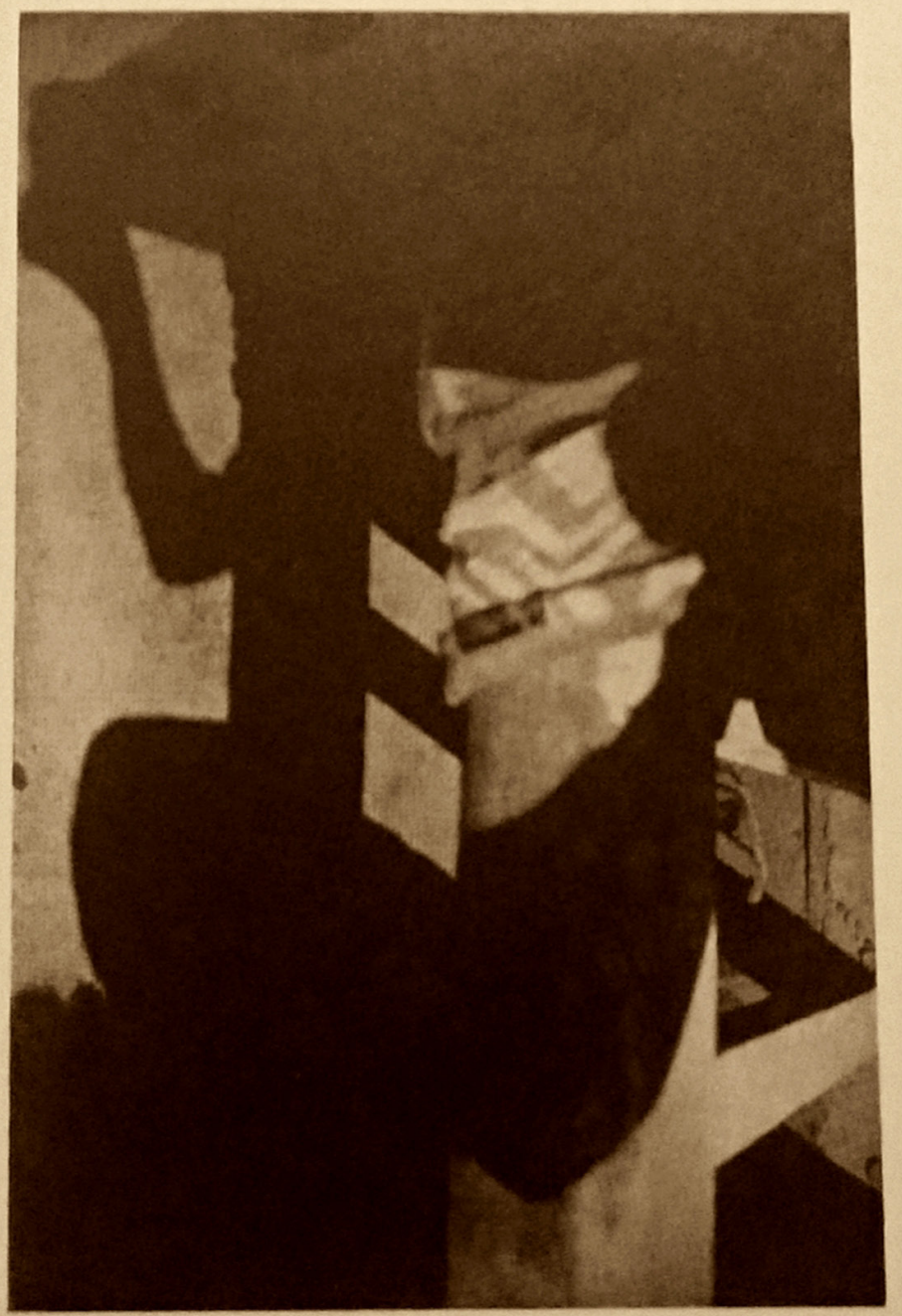

\section{Passage entre deux prises de vues}

Fonte: Cheroux e Ziebinska-Lewandowska (2015, p. 81). 
e) Surpresas:

Imagem 25 - A Velha Câmera (Segunda Imagem), de Mariusz Hermanowicz (1981).

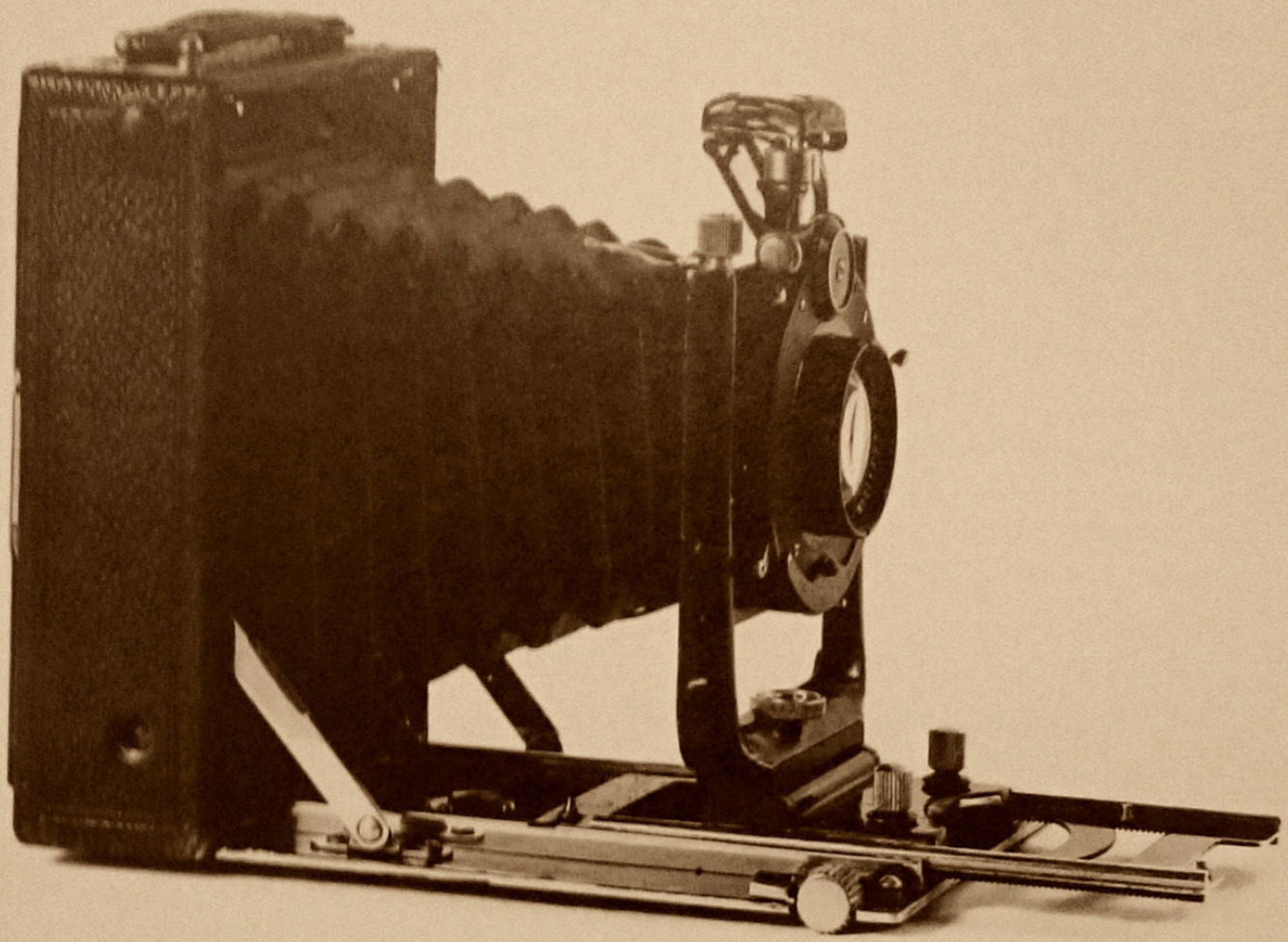

Voici justement ce vieil appareil

Fonte: Cheroux e Ziebinska-Lewandowska (2015, p. 87). 
5) Bloco "Alquimia" com os sub-blocos:

a) Uma fase obscura:

Imagem 26 - Não confie seus filmes ao acaso, só um especialista pode obter deles o máximo!, estudo publicitário de Gaston Karquel (1938).

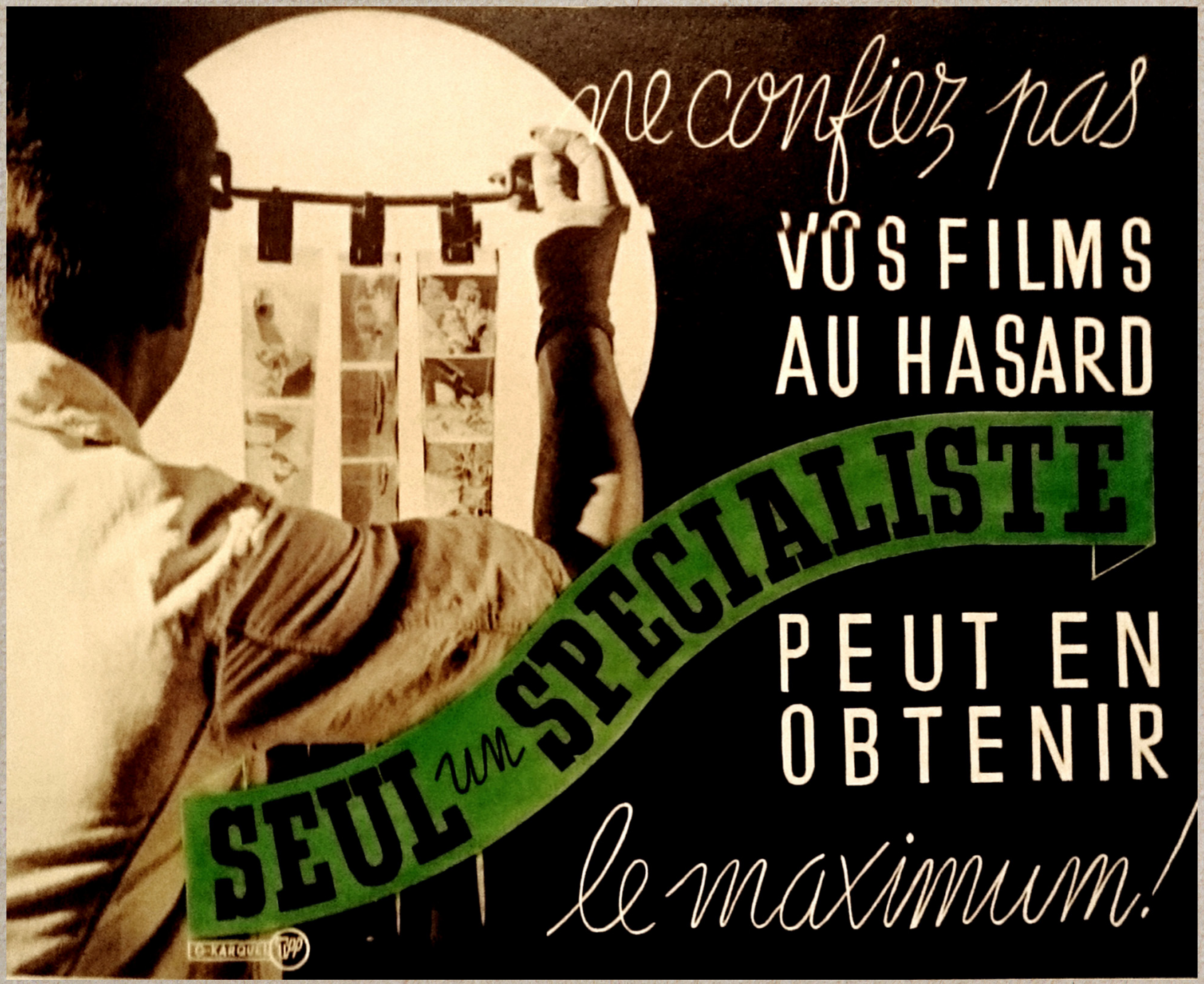

Fonte: Cheroux e Ziebinska-Lewandowska (2015, p. 97). 
b) A coisa e seu contrário:

Imagem 27-O Sole a Lua a partir de um só Negativo [díptico], de Timm Rautert (7972).

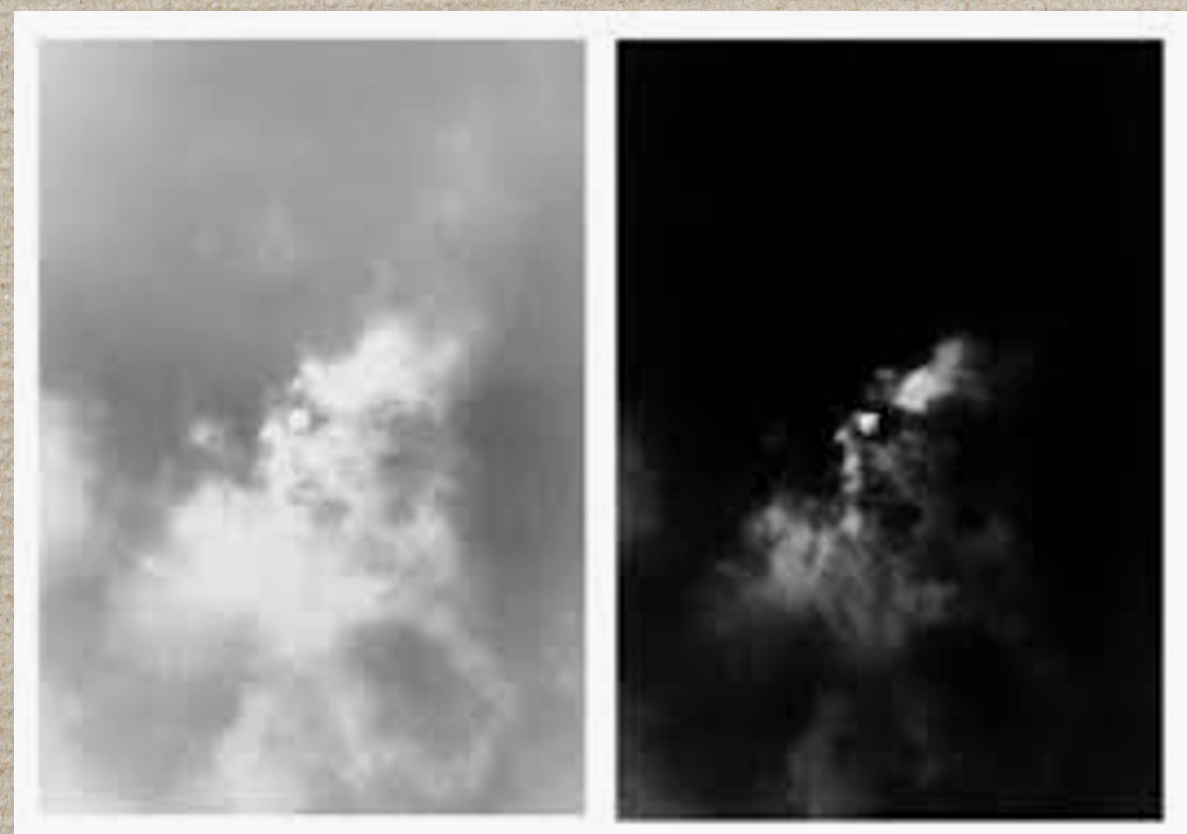

Fonte: Cheroux e Ziebinska-Lewandowska (2015, p. 99-101).

c) Alegoria da caverna:

Imagem 28 -Sem título 7987, de Michel Campeau (2005-2010).

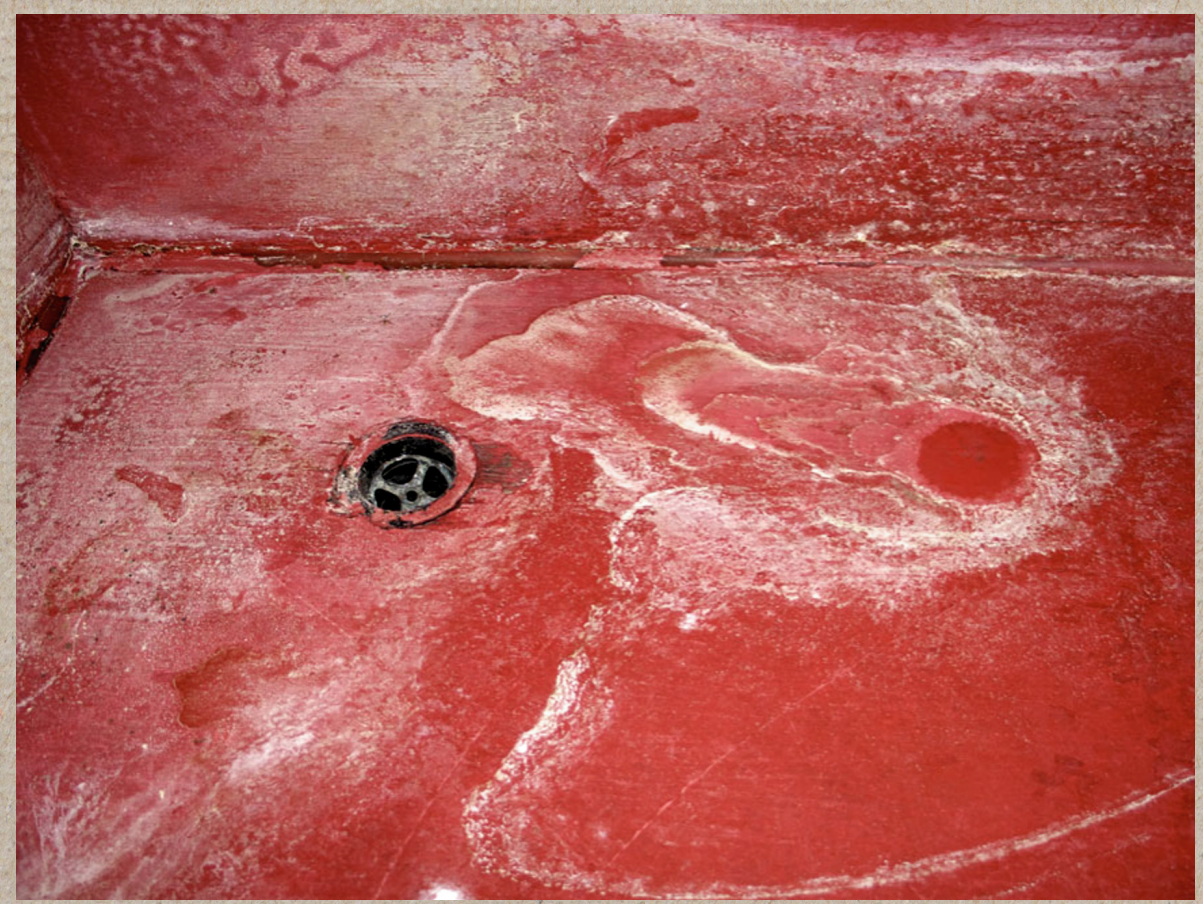

Fonte: Cheroux e Ziebinska-Lewandowska (2015, p. 105). 
6) Bloco "Lacuna", com os sub-blocos:

a) O que resta:

Imagem 29-A história das Flares II [políptico], de ]an Saudek (1987).
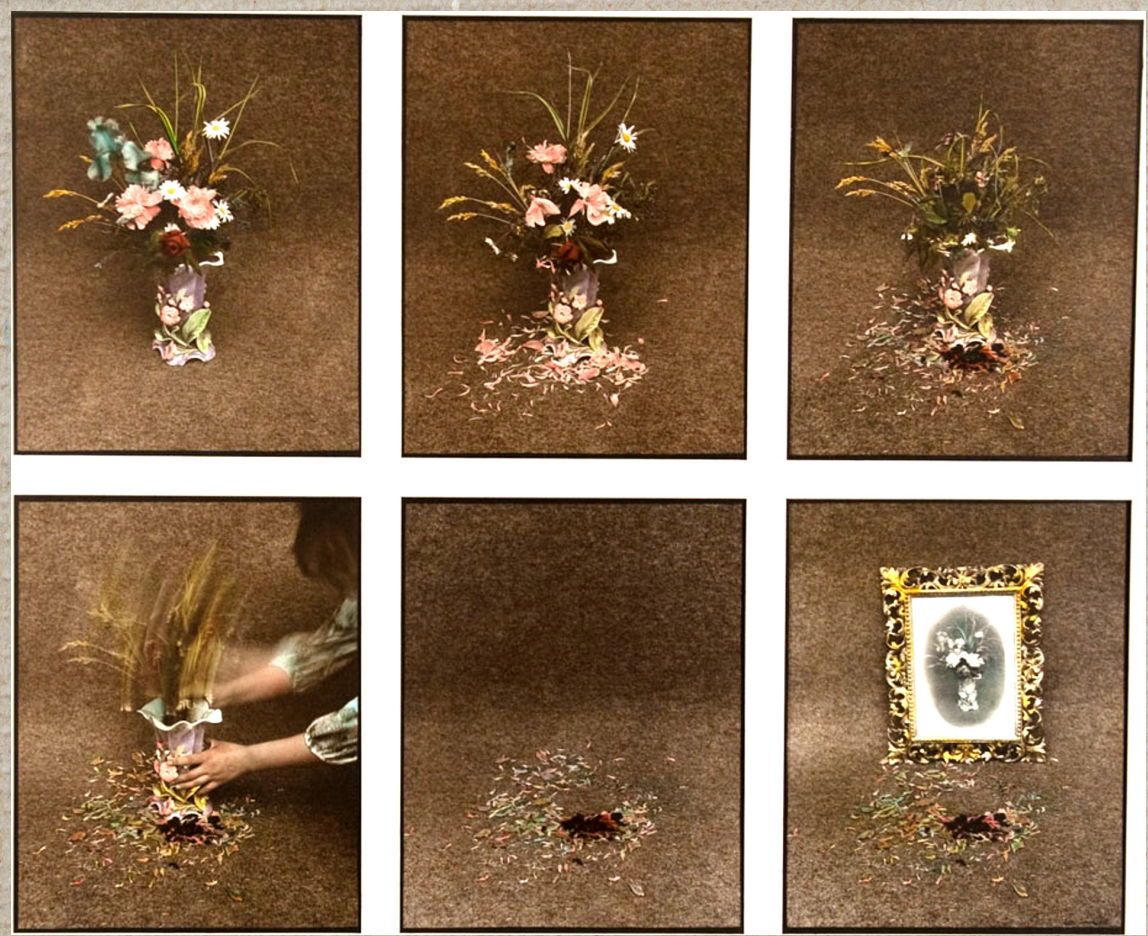

Fonte: Cheroux e Ziebinska-Lewandowska (2015, p. 109-114).

b) Reflexos:

Imagem 30 - Imagem para as mulheres, de Jeff Wall (1979).

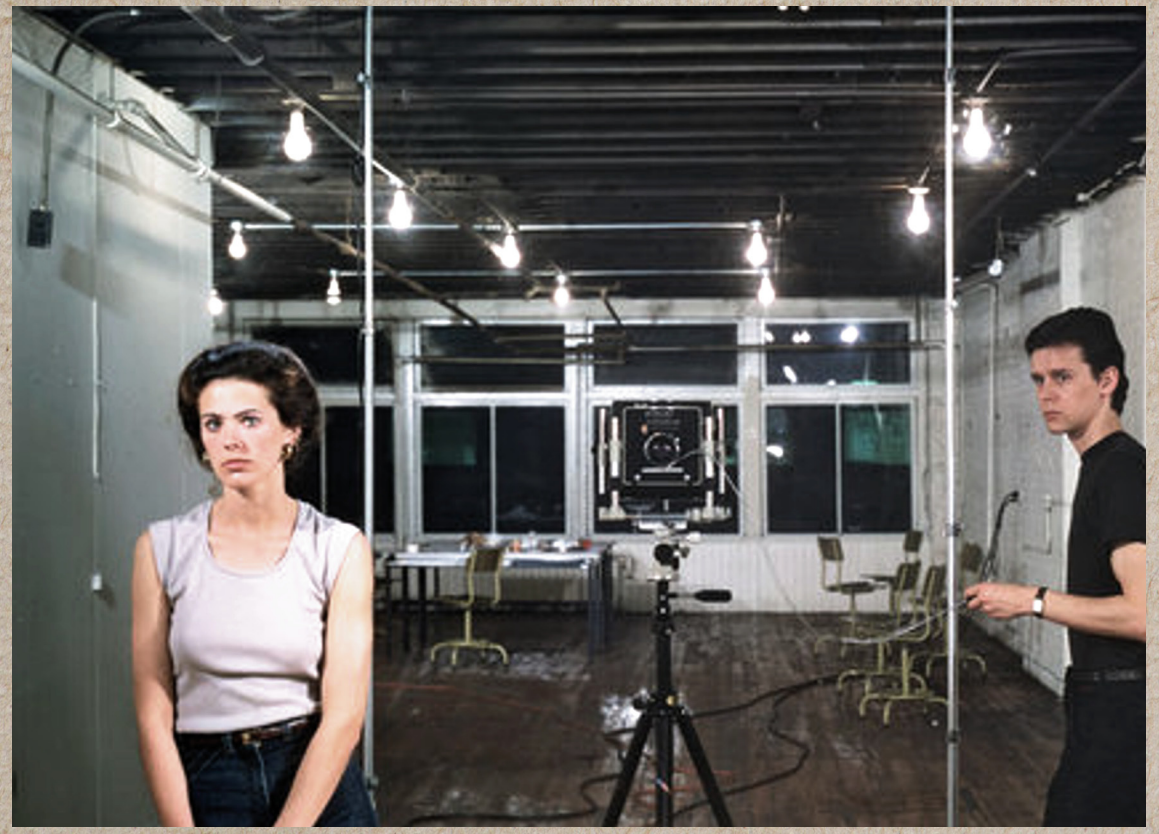

Fonte: Cheroux e Ziebinska-Lewandowska (2015, p. 117). 
c) Uma aura a mais:

Imagem 31 - Registro de Jochen Cerz ao lado de sua reprodução fotográfica [documentação de performance] (7972).

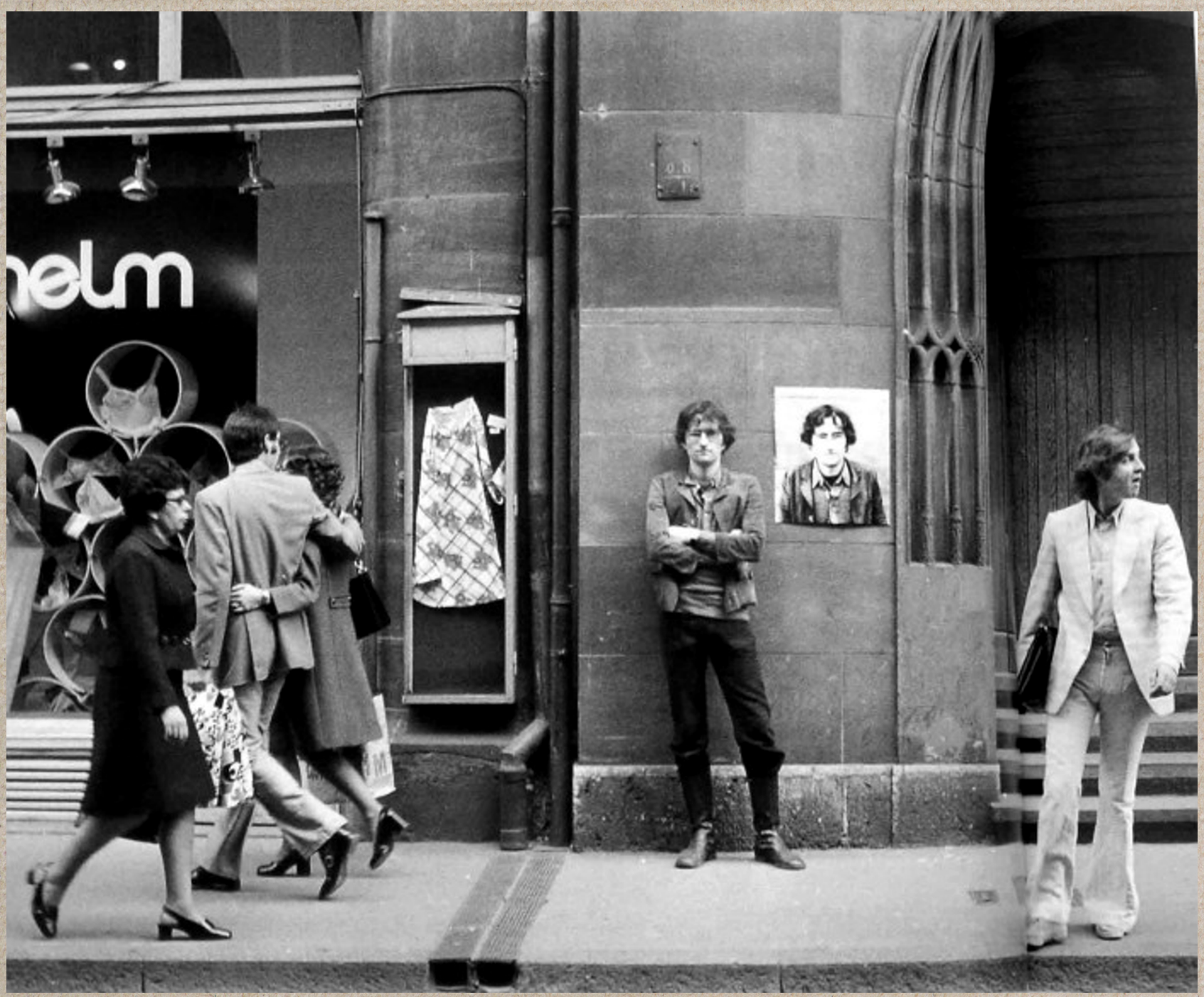

Fonte: Cheroux e Ziebinska-Lewandowska (2015, p. 119). 
d) Uma interpretação simbólica:

Imagem 32 -Imagem Cabeça, de Douglas Cordon (2001).

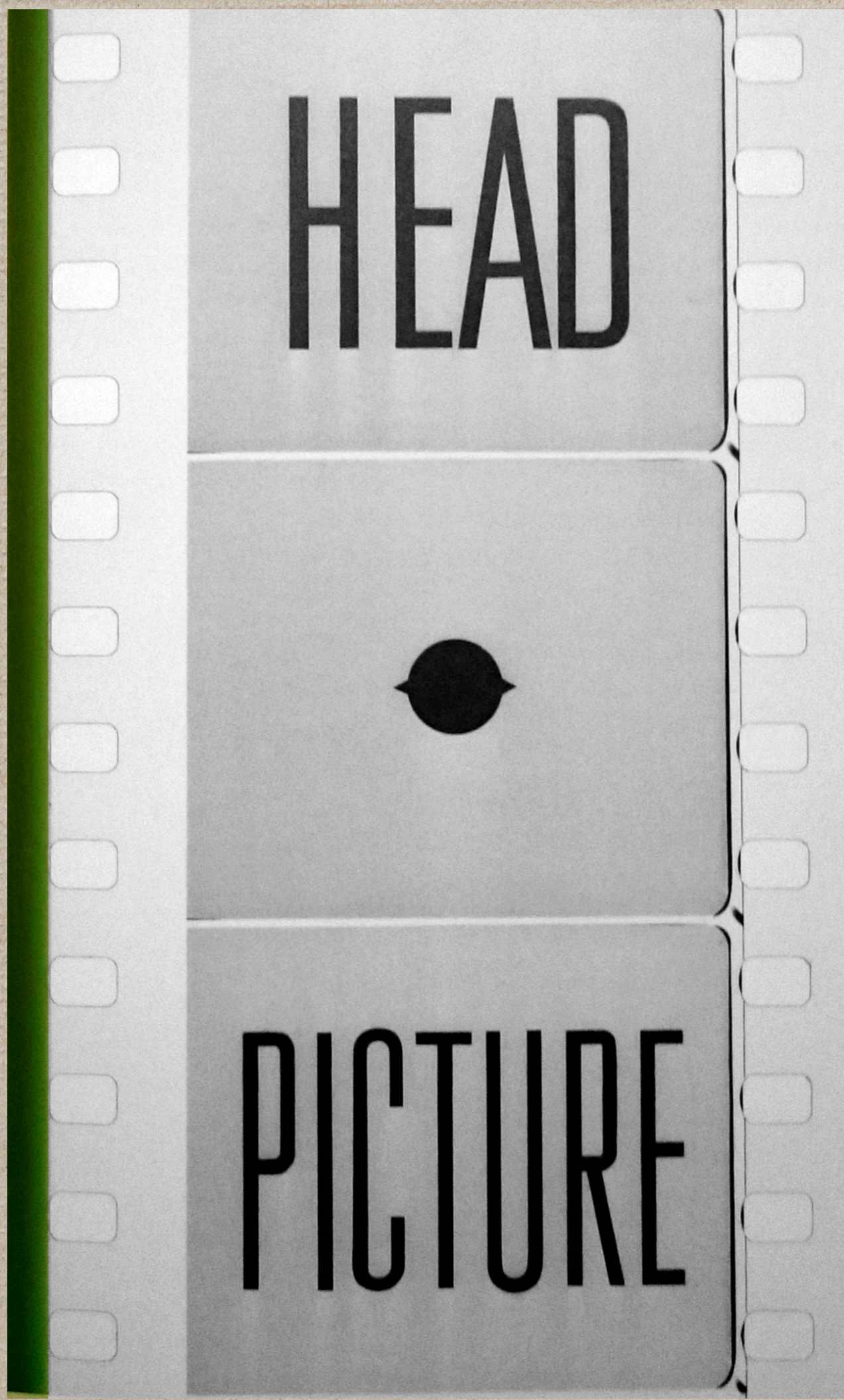

Fonte: Cheroux e Ziebinska-Lewandowska (2015, p. 121). 
7) Bloco "Recursos", com os sub-blocos:

a) Suportes de difusão:

Imagem 33 - Tríptico \#1, de Jean-Louis Garnel (1992).
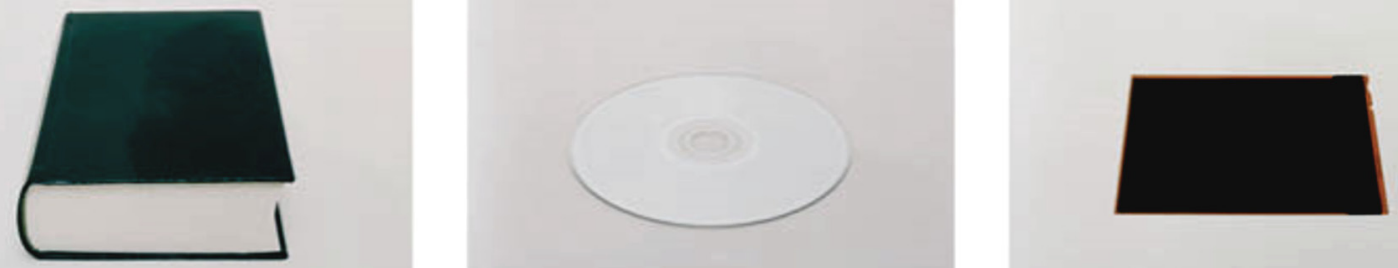

Fonte: Cheroux e Ziebinska-Lewandowska (2015, p. 125-127).

b) Redução do mundo:

Imagem 34 - As imagens, de Florence Paradeis (1995).

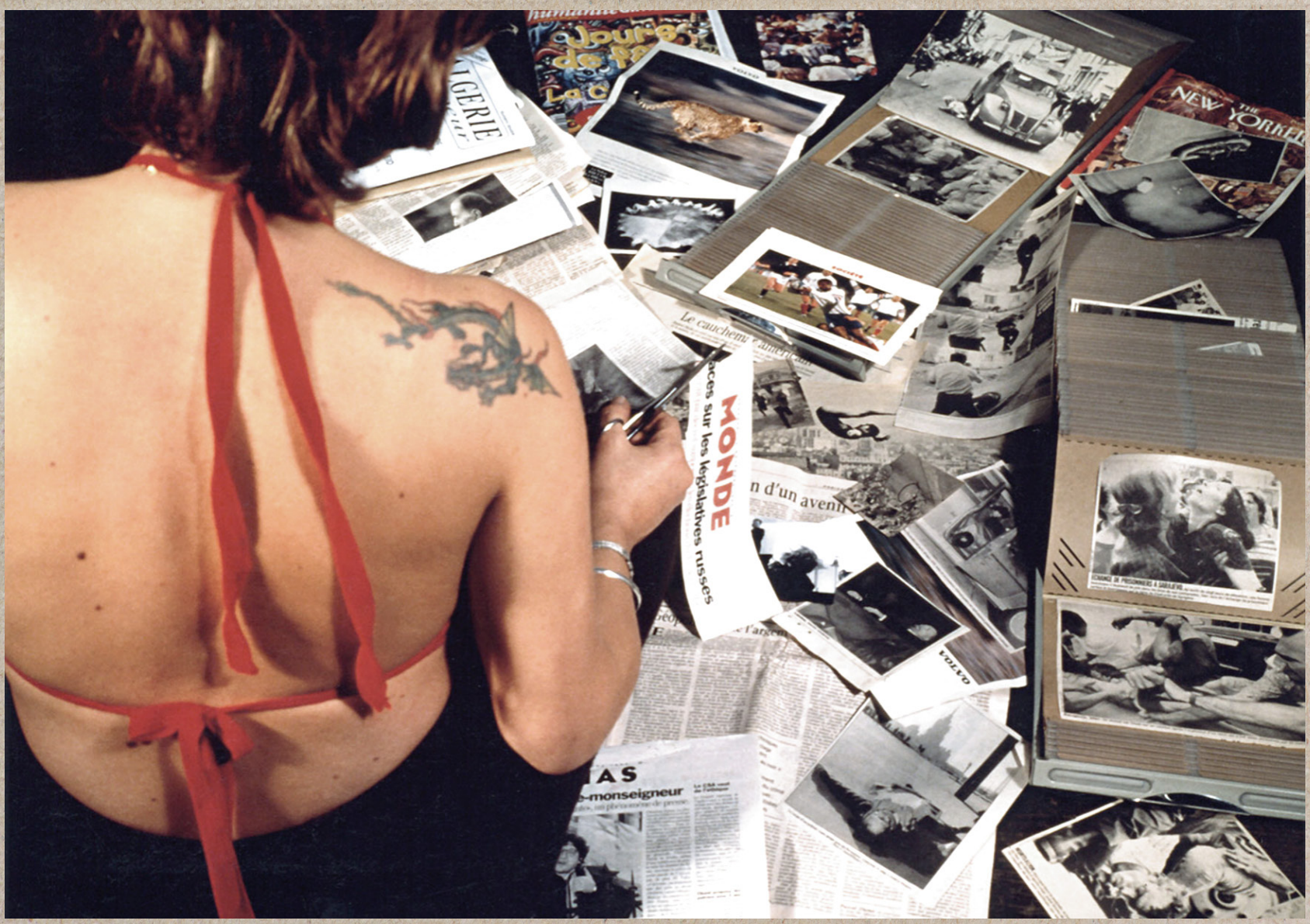

Fonte: Cheroux e Ziebinska-Lewandowska (2015, p. 129). 
c) Chaves para compreender:

Imagem 35 - Caixa de Fósforos, de Man Ray (1960).
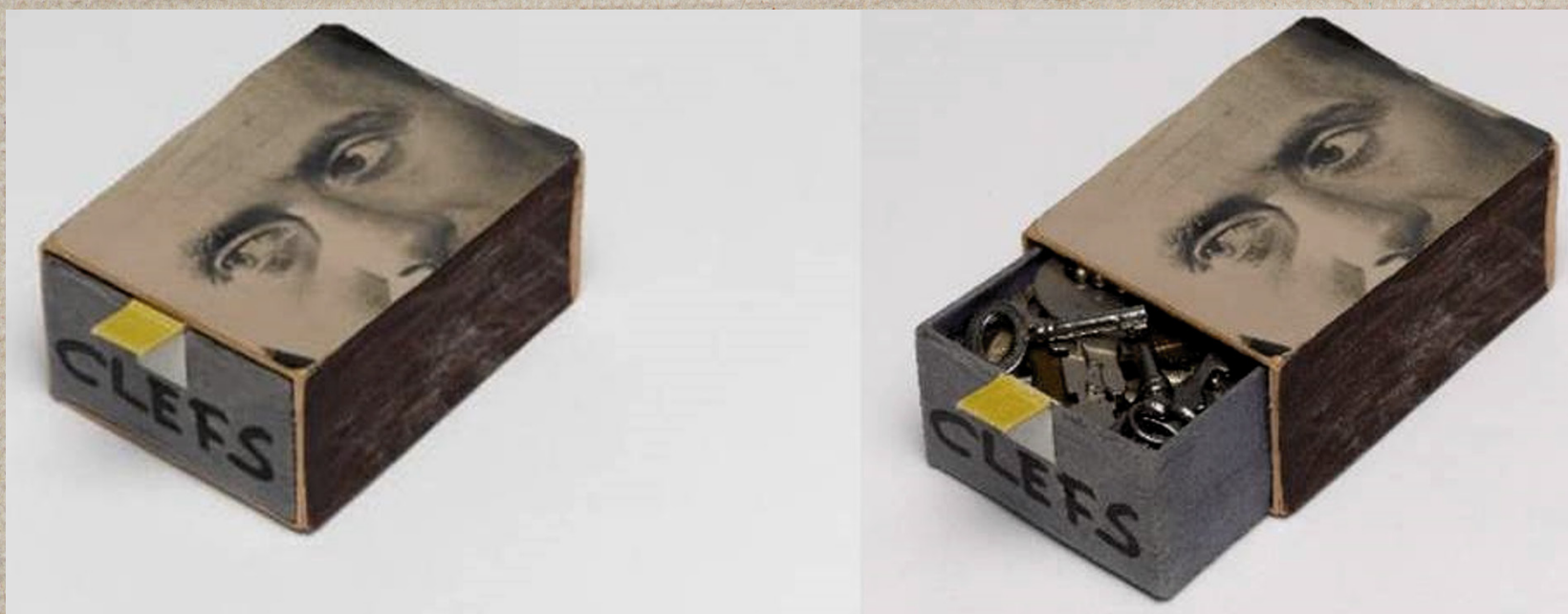

Fonte: Cheroux e Ziebinska-Lewandowska (2015, p. 131-133).

d) Um enigma insolúvel:

\section{Imagem 36-Cabinete fotográfico, de Robert Morris (1963-1975).}

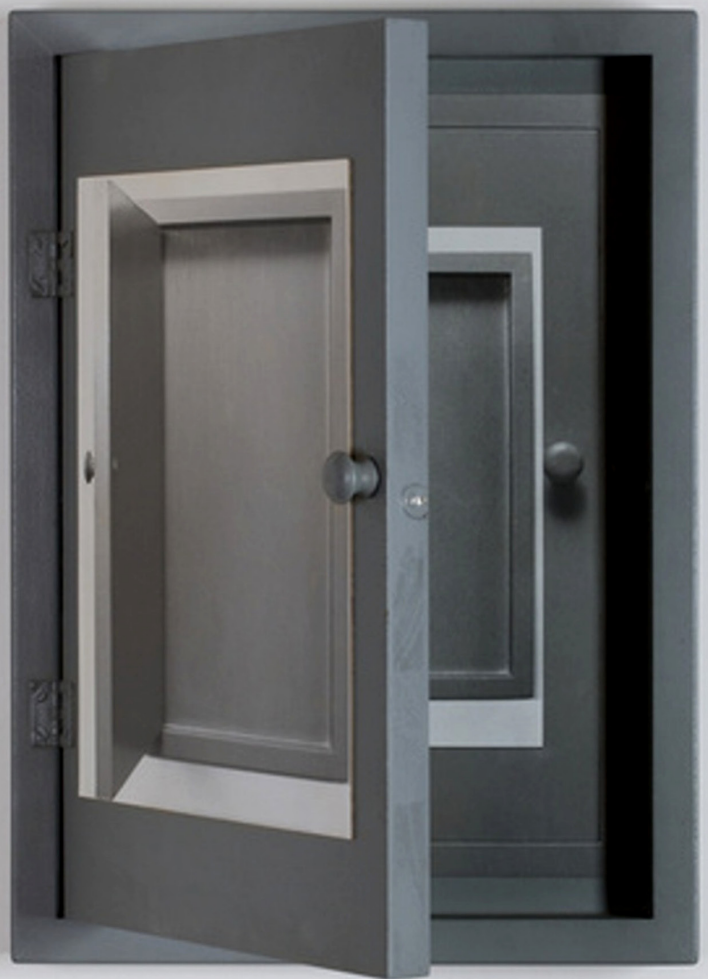

Fonte: Cheroux e Ziebinska-Lewandowska (2015, p. 135). 
No catálogo, todos os blocos temáticos são abertos por uma definição, extraída da Grand Larousse de la Langue Française (apud CHÉROUX, 2015, p. 30) e cada subtema, com a obra que apresenta, é acompanhado de uma introdução ao artista e à obra em si. Uma apresentação bastante didática, que abrange, de forma básica, a história do autor e o processo de produção da imagem exposta, finalizando com o ponto de vista do curador. Todos os textos são de autoria de Clément Chéroux, ora mais pedagógico, ora mais sensível, sobre o porque daquela produção ajudar a responder, a partir do lugar em que se aloca, à questão "O que é a Fotografia?".

\section{No Brasil}

Embora diferentes na concepção, nas proposições e na forma como refletem e debatem sua pergunta título, ambas a exposições, ou seja What is a photograph? ou Qu'est-ce que la photographie?, vão de encontro às quéstões recorren- tes sobre os limites do fazer e pensar a fotografia e às rupturas dadas pela ação do artista e pela imagem fotográ-, fica a todo tempo; questões trazidas também no Brasil, por sólidas instituições museológicas, como é o caso do Museu de Arte Contemporânea de São Paulo (MAC/USP) e do Museu de Arte Moderna de São Paulo (MAM/SP).

No caso do MAC, uma exposição realizada entre 28 de setembro de 2013 e 3 de maio de 2015, intitulada Fronteiras Incertas (Imagens 37 e 38), com curadoria de Helouise Costa, propôs o debate sobre o apagamento das fronteiras entre as artes, as épocas, os territórios e os indivíduos produtores de obras que, de alguma forma, são perpassadas pelo fotográfico ou constituídas essencialmente por ele, dando destaque especial para o conjunto de produções experimentais polonesas pertencentes ao acervo do MAC desde a década de 1970 e exibido pela primeira vez naquela exposição, como carro chefe da mostra; e ponto de partida para os diálogos entre obras propostos. 


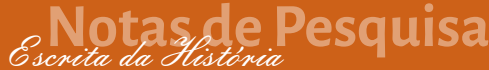

Imagem 37 - Fronteiras Incertas [montagem da exposição].

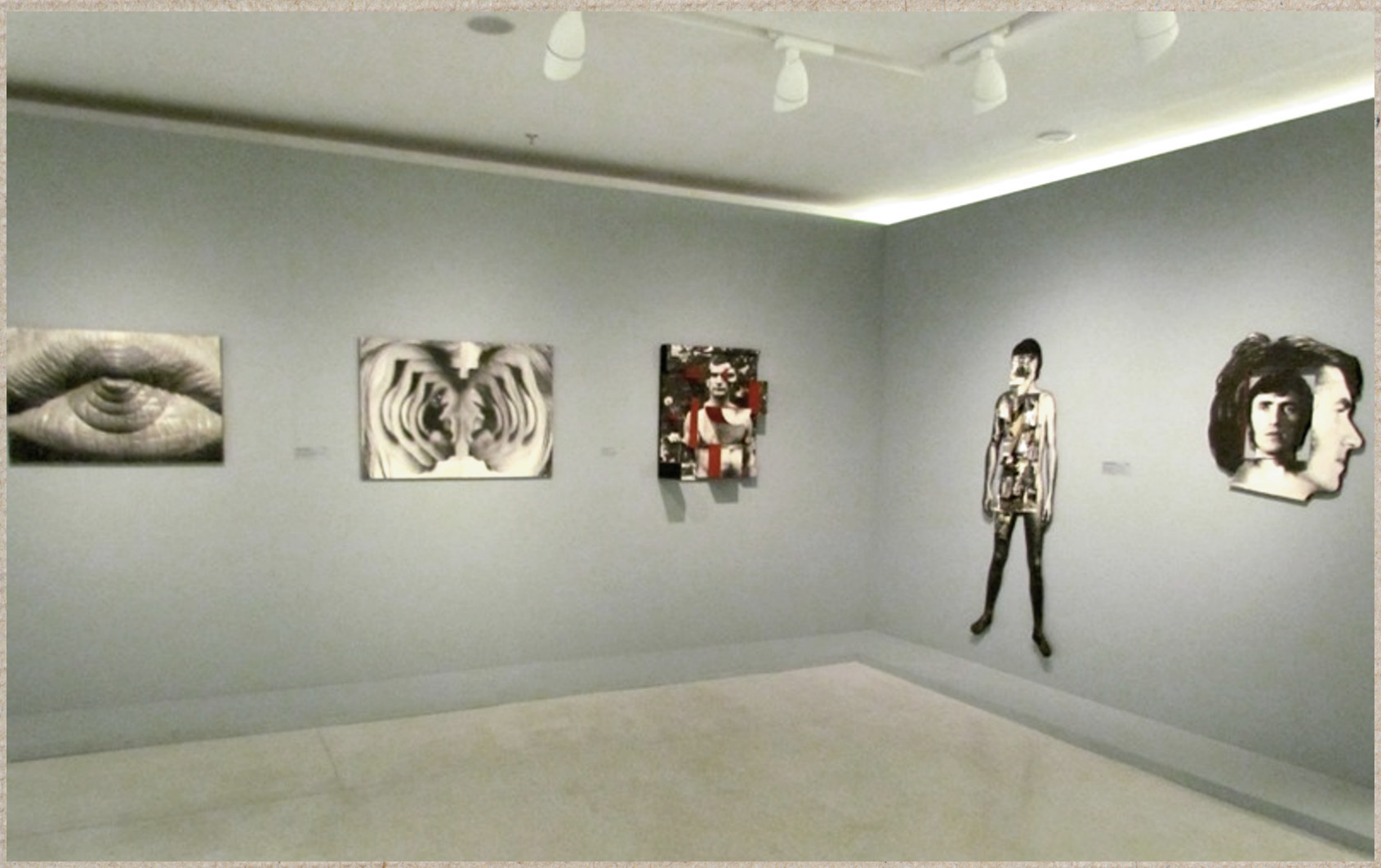

Fonte: Fotografia elaborada pela autora (2014)

Imagem 38 - Registro e detalhe da obra "Sem título (Homem em Tamanho Natural)", de Antoni Mikolajczyk (1973).

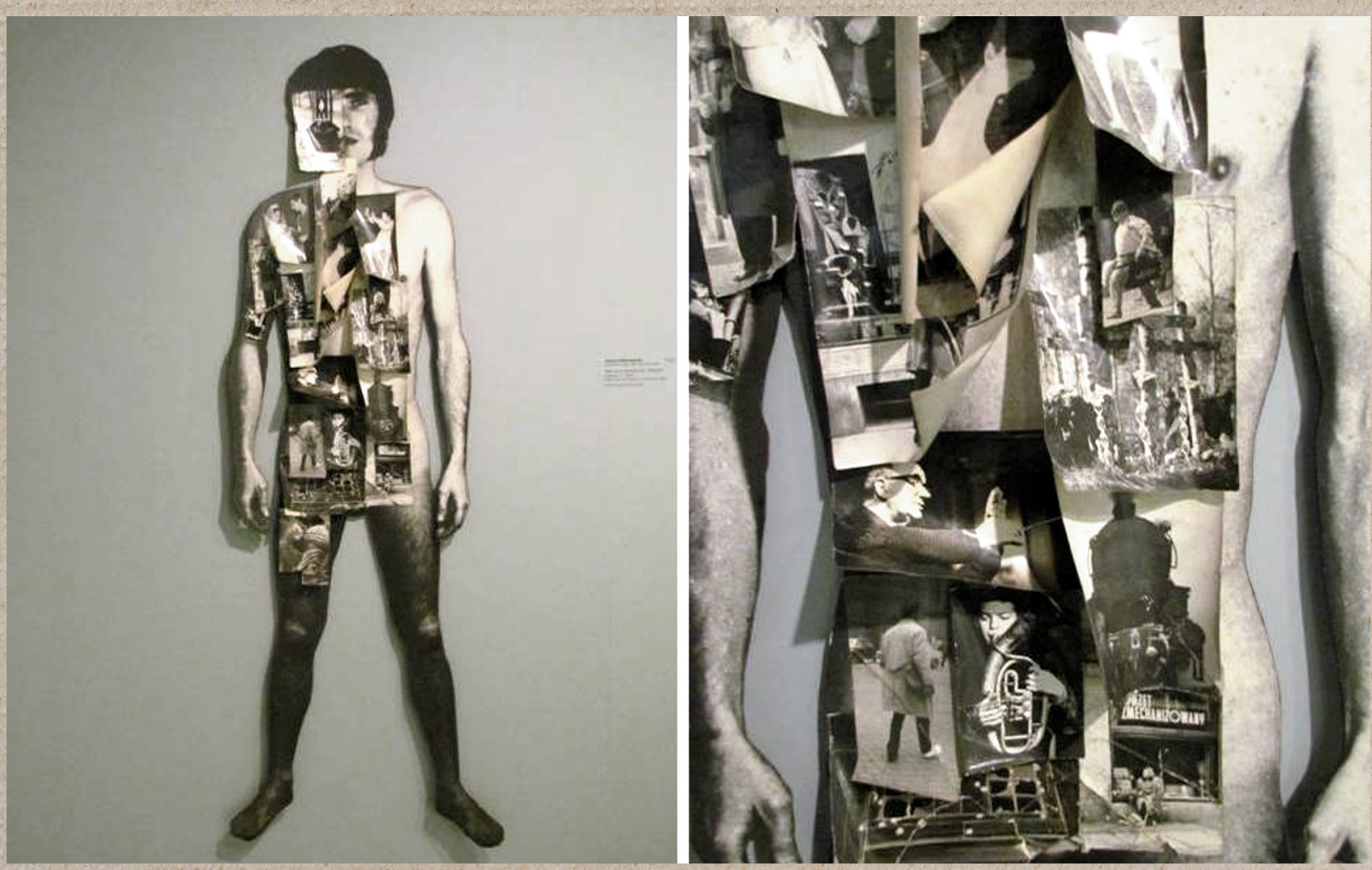

Fonte: Fotografia elaborada pela autora (2014). 
Junto com os artistas poloneses e suas obras, na maioria conceituais e objetuais, vemos, entre outros nomes, Rafael Assef, Jan Saudek, Waldemar Cordeiro, Joel-Peter Witkin, Cris Bierrembach, Hudnilson ]r., John Coplans, Cristiano Mascaro, Maureen Bisilliat, Rochelle Costi, Claudia Andujar, Odires Mlászho, Paulo de Andrade, Cássio Vasconcelos, Mário Cravo Neto, Boris Kossoy, Claudia Jaguaribe e Pedro Meyer, numa mescla de trabalhos e conversas imagéticas que vão desde registros cotidianos, sociais e de paisagens, até daguerreótipos, intervenções artísticas, hibridizações/referenciações variadas, fotocópias e instalações mecânicas ou esculturais-fotográficas. A proposta da exposição coincide com a análise de Ronaldo Entler quando, por ocasião da exposição A Invenção de um Mundo (Coleção da Maișon Européenne de La Photographi, Paris), realizada em 2009 no Itaú Cultural, sob curadoria de Eder Chiodetto e Jean-Luc Monterosso, escreve:

Permanece difícil encontrar uma palavra capaz de agrupar tais experiências, algo que nos explique efetivamente aquilo que se chamou de fotografia contemporânea. Esboçaram-se algumas tentativas, sempre insuficientes e provisórias: falou- -se numa fotografia construída, híbrida, contaminada... Mas, enquánto levava ao limite as possibilidades de transgressão técnica e ficcionalização, essa mesma fotografia nos ajudou a perceber o quanto havia de impuro e de imaginário na própria experiência documental a que se opunha (ENTLER, 2009).

Pelo próprio título, a exposição nos encaminha à recorrente discussão entre documental e ficção; entretanto, mais do que tudo, a mostra traz à luz a questão fundamental da impossibilidade contemporânea de definir e enquadrar uma obra de arte não específica, situação que debateremos mais adiante.

O Museu de Arte Moderna de São Paulo também discute esse tema desde que a fotografia "dos artistas", como diria André Rouillé, passou, com maior ênfase, a fazer parte de seu acervo e de suas exibições temporáriaś, mais marcadamente a partir do final da segunda metade da década de 1990.

Duas mostras chamam atenção nesse sentido: a primeira delas, Fotografial não fotografia, de curadoria de Rejane Cintrão, aconteceu na sala II do MAM entre fevereiro e março de 2001. Com obras do acervo do Museu, demons- 
trava a diversidade da produção contemporânea de fotografia experimental no Brasil, propondo a reflexão e o debate sobre possibilidades expressivas que a fotografia, como suporte e veículo, apresenta, em especial através da produção de artistas "não fotógrafos" . A iniciativa partiu de um convite à curadora para uma mostra coletiva em Guadalajara (América Foto Latina, 2000), onde curadores de vários países da América Latina foram convidados a mostrar o que vinha sendo produzido de mais interessante em cada país no que tange à fotografia.

\section{Imagem 39 - Sem Título, de Fabiana Rossarola (1999).}

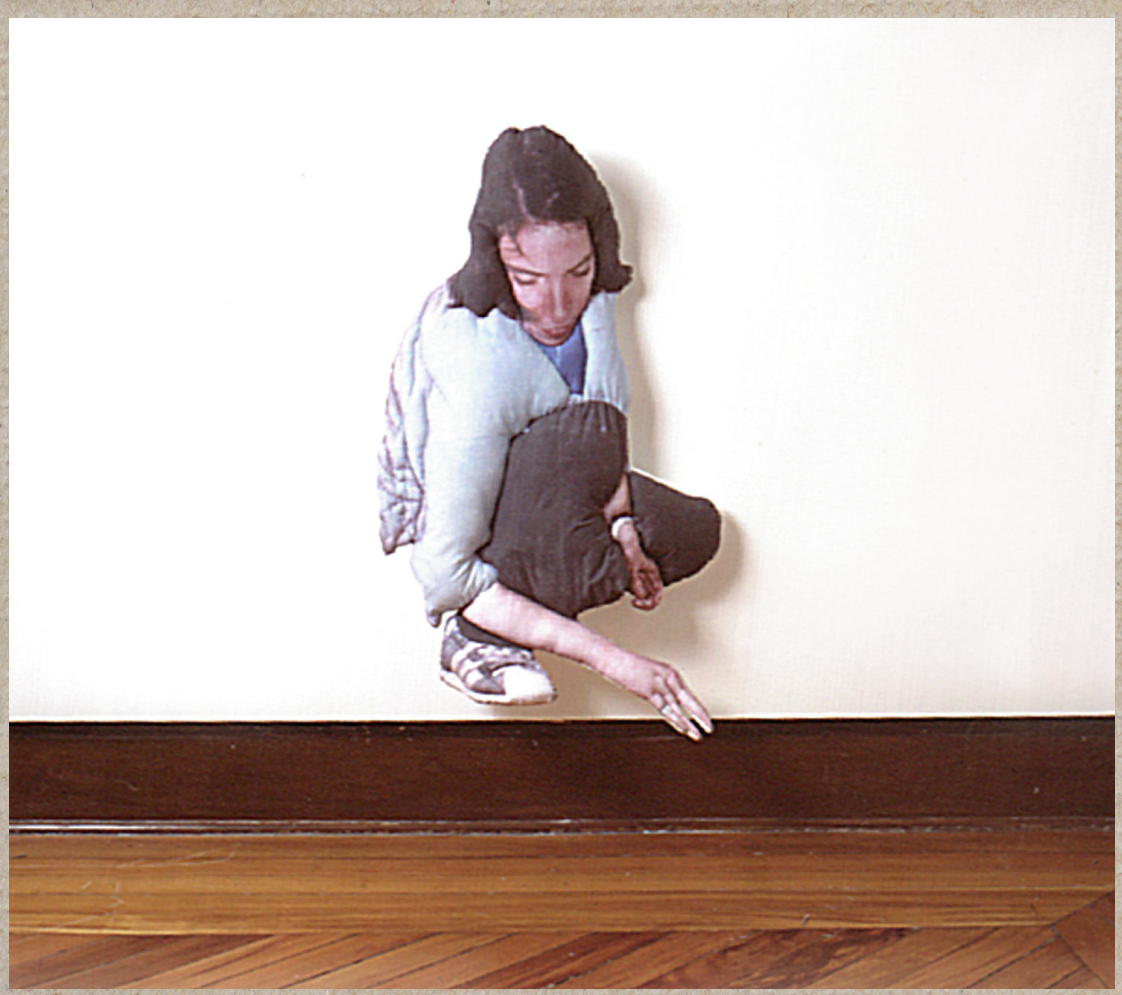

Fonte: Museu de Arte Moderna de São Paulo,(2014)

5 Palavras de Rejane Cintrão, em entrevista concedida à autora, no dia 22/09/2015, em São Paulo.
Cintrão elaborou sua seleção a partir da coleção do MAM, que se encontrava na época em seu auge de abarcamento de, obras experimentais, a partir da condução de Tadeu Chiarelli, que entre 1996 e 2001 contribuiu consideravelmente para a ampliação e atualização do acervo fotográfico do museu, levando para Guadalara artistas como Albano Afonso, Amilcar Packer, Cris Bierrenbach, Dora Longo Bahia, Fabiana Rossarola (Imagem 39), Gustavo Rezende, Márcia Xavier, José Luiz de Pellegrin, Rafael Assef, Rochelle Costi, Rosana Paulino (Imagem 40), Rosângela Rennó, Sandra Cinto e VikMuniz-autores das obras que, posteriormente, comporiam a exposição Fotografial Não Fotografia, em 2001. Segundo a curadora, o objetivo era mostrar a atualidade da produção fotográfica brasileira e, ao mesmo tempo, demonstrar sua variedade e riqueza a partir de obras produzidas por artistas que nunca foram, necessariamente, fotógrafos. 


\section{Notas de Pesclyisa}

Imagem 40-Sem título, de Rosana Paulino [bastidores-detalhe].(1997).

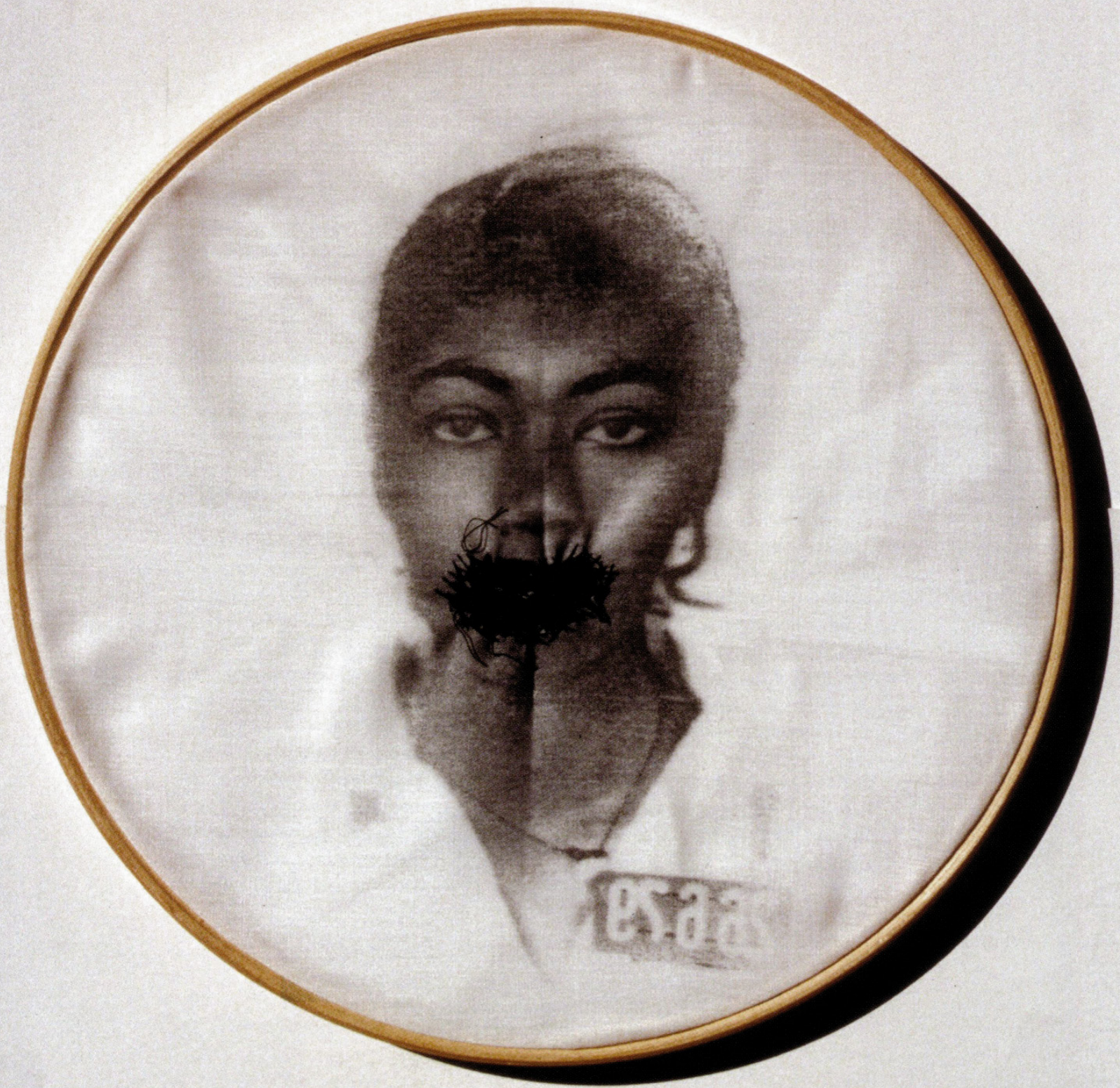

Fonte: Museu de Arte Moderna de São Paulo (2014). 
Também na exposição São ou Não São Gravuras, apresentada entre os dias 21 de junho e 2 de agosto de 2001, no espaço MAM Villa-Lobos, é colocado em debate o apagamento de fronteiras entre as especificidades, téc-

Imagem 41 - Reprodução da capa do folder da exposição "São ou não são gravuras", realizada no espaço MAM Villa Lobos (2007).

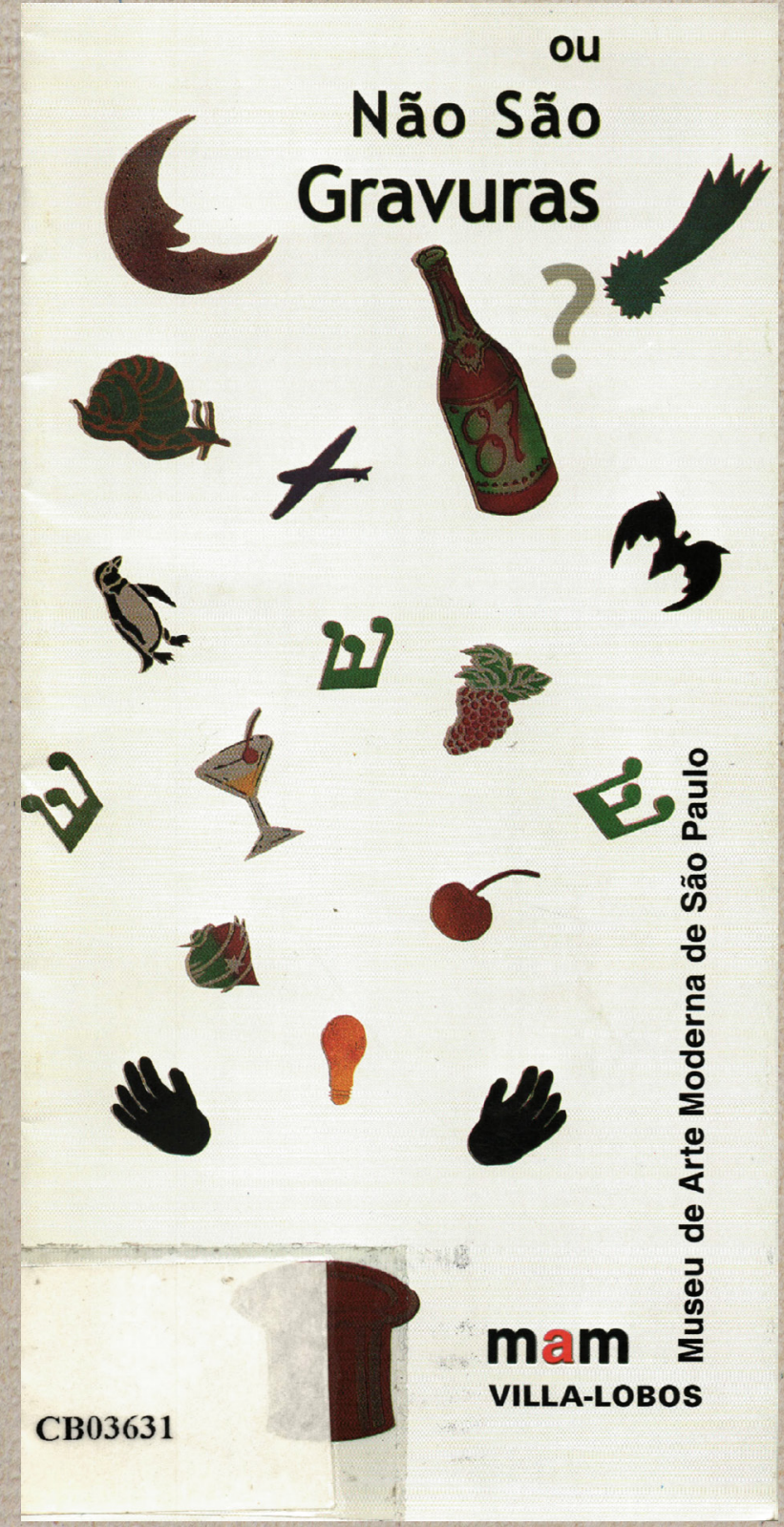

Fonte: Digitalizado pela autora (2014) nicas e suportes artísticos (Imagens 41 e 42). As obras selecionadas pela curadoria de Ricardo Resende para a. exposição intencionam evidenciar a quebra de limites na arte contemporânea e seguem desde uma apresentação escultural, até a apresentação de livros objeto, fotocópia, entre outros. A pesquisa de Ricardo Resende, no entanto, se passa a partir de uma sólida coleção já existente no museu, formada por meio de aquisições realizadas pelo Clube da Cravura do MAM.

Imagem 42 -Reprodução da parte interna do folder da exposição "São ou não são gravuras", realizada no espaço MAM Villa Lobos (2007).
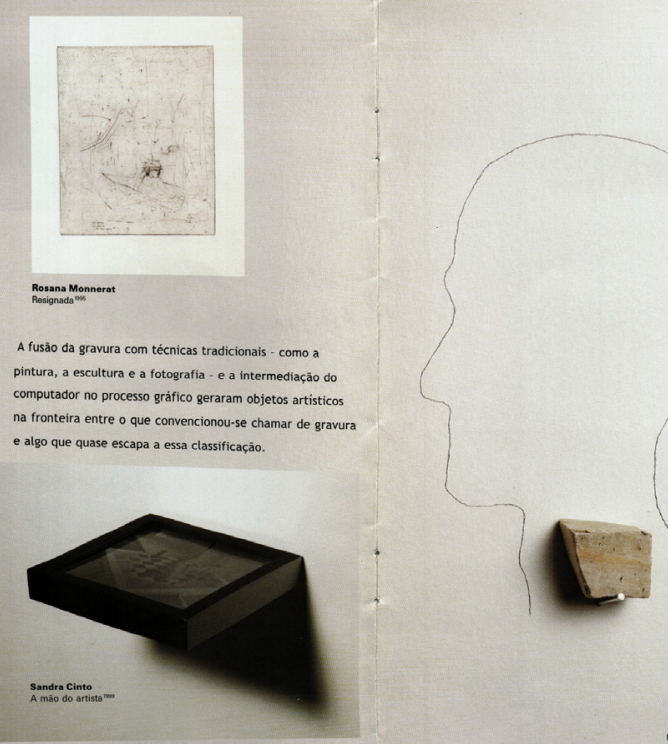

Fonte: Digitalizado pela autora (2014) 


\section{A fotografia e o discurso da arte contemporânea}

Por vias diferentes, todas essas exposições têm em comum, o fato de apresentarem obras que não desejam ser (apenas) fotografia e artistas que não intencionam ser (apenas) fotógrafos. Esse é o primeiro ponto importante a ser discutido.

Quando digo que não são "apenas fotografias" e nem "apenas fotógrafos", não intenciono absolutamente a defesa de uma fotografia experimentale híbrida, ou construída, em detrimento de uma fotografia documental, autoral, que aporta excelência técnica e de revelação/impressão-embora seja a primeira que interesse às minhas pesquisas.

Muito menos, pretendo defender a superioridade dos artistas em relação aos fotógrafos.

Porém, no potente caos do contemporâneo no qual nos encontramos, é preciso, ainda dentro de um questionamento sobre o que é a fotografia - ou a arte, ou a vida ela mesma -, compreender que algumas coísas não são de- finíveis, enquanto outras, conseguem ainda manter certo espaço marcado.

Nesse sentido, alguns fotógrafos e algumas fotografias, ambos contemporâneos, têm seu lugar claro e bem delimitado, seja no fotojornalismo, ou no trabalho de documentação autoral, como faz, por exemplo, Sebastião Salgado. Essas fotografias podem ser mais ou menos ortodoxas dentro de seus propósitos e âmbitos técnicos, categóricos ou de assunto, ou mais claramente construídas expressivamente - fotografia criativa, como já tratou Lemagny (1984) - ou ainda pertencentes a uma tentativa de registro neutro (embora com recortes escolhidos), que o fotógrafo determina, opta e trabalha para alcançar. Fotógrafos que, muitas vezes, não estão interessados na plasticidade da mesma forma que os artistas estão, mas por um viés espécífico, que é o de exploração das técnicas e das possibilidades que o aparelho e o meio oferecem às suas produções fotográficas. Desejam, portanto; produzir fotografias: jornalísticas, documentais e/ ou artísticas. E produzem. Têm seus trabalhos legitimados no próprio campo e nos museus, que desde a criação do primeiro 
departamento de fotografia, inaugurado porBeaumont Newhall, em 1940 , no MoMA de Nova lorque, acolhem as fotografias dos fotógrafos, Ihes concedendo, oficialmente, desde aí (já que em algum momento foi preciso), seu estatuto de arte. E essas produções, que seguem da metade do século $X X$ até os nossos dias, são todas fotografias contemporâneas.

Por outro lado, há outra exploração, e mais do que isso, experienciação do fotográfico e da fotografia no campo da arte - (também) contemporânea - a qual não mais é possível definir e deli-

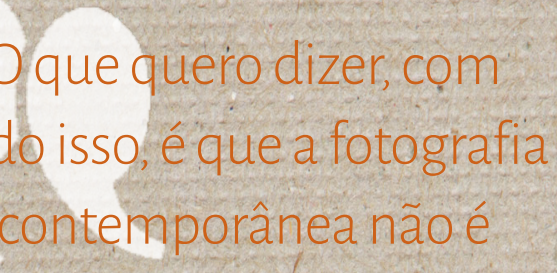
uníssona. Ela não é isso ou aquilo. Eláé, como sempre foi, plural, e ligá-la a um só desses seus muitos lados

é, de qualquer forma, reduzi-la - reduzindo inclusive as possibitidades de questionamento que o fotográfico sempre. nos apresentou, desde suas origens, Fotografia contemporânea é um termo muito amplo, e é preciso cuidado aio tratar o assunto. Fotografia contemporânea pode ser muita coisa. quer forma, reduzi-la - reduzindo inclusive as possibilidades de questionamento que o fotográfico sempre nos apresentou, desde suas origens. Fotografia contemporânea é um termo muito amplo, e é preciso cuidado ao tratar o assunto. Fotografia contemporânea pode ser muita coisa.

O que tenho observado numa grande parte de estudos e reflexões sobre o fotográfico na contemporaneidade é certo equívoco quanto à mitar, assim como não é possível definir e delimitar o trabalho dos artistas que produzem obras a partir dessas experiências. compreensão e tratamento do que é, ou melhor, pode ser essa tal fotografia contemporânea.

Em geral, liga-se o termo a toda a O que quero dizer, com tudo isso, é gama de produção experimental que que a' fotografia contemporânea não é utiliza o meio hibridizado, ou a partir 
da construção de cenas, ou a partir de toda a variedade (im) possível de usos da fotografia na arte.

A meu ver, o fato que mais importa quando definimos algo qualquer que seja como contemporâneo, é essencialmente a época em que ocorre, seu tempo histórico. Contemporaneidade na história é tudo o que de fato se passou ou se passa num tempo atual ou recente (um recente histórico, que se tenha claro, e não um recente imediatista). Isso que começa a acontecer (ou aparecer com mais força) com a arte a partir dos anos 1960 e 1970 e que ganha força, dali para frente e cada vez mais, pode ser chamado de arte contemporânea hoje, mas daqui a alguns anos estará alocado, historicamente, com uma nomeação que não sabemos ainda qual será, mas que me parece tendenciosa a ser extraída do conceito e da ideia de experimental, já que a arte contemporânea é a arte da experimentação em muitos sentidos.

Tomemos o caminho para onde quero chegar, retomando o texto de Ronaldo Entler (2009):

Com contornos escorregadios, resta apreender que, mais do que um procedimen'to, uma técnica, uma tendência estilísti- ca, a fotografia contemporânea é uma postura. Algo que se desdobra em ações diversificadas, mas cujo ponto de partida é a tentativa de se colocar de modo mais, consciente e crítico diante do próprio meio. Alguns recortes são esclarecedores. Podemos reconhecer nas propostas que assumem uma direção ficcionalizante, [...] uma experiência fundamental para a afirmação dessa postura

trecho traz uma chave fundamental para começarmos um esboço de compreensão ou atenção para essas obras que envolvem o fotográfico no campo da arte: a ideia e o princípio de "uma postura contemporânea”. E desde aí, me interessa pensar também, o termo cunhado por Dominique Baqué (2007, p. 6-13) para definir essa produção: o extremo contemporâneo. Segundo a autora, os anos 1980 marcam a desconstrução definitiva da mitologia modernista de salvaguardar a pureza da arte e autonomia das especificidades da contaminação das mídias, e a fotografia tem papel fundamental nesse sentido. Para ela, ainda que "subsistam, aqui ou ali, fotografias 'puras', isso não muda nada a avaliação que devemos fazer sobre a situação do campo contemporâneo: é quase impossível para uma obra, hoje, reivindicar sua autonomia. [...] Em geral, o heterogêneo se tornou a regra". 
Entretanto, é a partir dos anos 1990, de acordo com Baqué, que nos vemos atracados no extremo contemporâneo; situação que, para ela, ultrapassa o desgastado termo pós-modernismo e nos coloca, no que tange ao fotográfico, num lugar marcado pela caducidade e pelo desuso de determinados questionamentos e debates em torno da fotografia.

\section{Voltando ao texto de Ronaldo Entler} (2009), vemos que ele converge com a autora quando afirma que essa operação de mudança no estatuto da arte e da fotografia começa a acontecer quando

muitos artistas deixaram de se perguntar que tipo de arte estavam fazendo e, assim, transitaram indistintamente entre diversas linguagens, incorporaram técnicas ainda mais alheias à tradição artística, como a serigrafia, o xerox ou meios eletrônicos insipientes, e realizaram experiências hibridas. que hoje chamamos de performances, instalações, ações, proposições, e outras tantas coisas difíceis de nomear. É interessante também pensar que a fotografia penetrou efetivamente os espaços da arte de um modo tanto mais evidente quanto menos esteve preocupada em responder aos fantasmas históricos que interrogavam sobre sua legitimidade artística. Esse momento se encarregou de exorcizar tais fantasmas de uma forma radical: a questão de saber se a fotografia é ou não uma obra de arte se esvazia quando ninguém está preocupado em definir se uma obra é où não fotográfica, ou pictórica, ou videográfica etc.
Tanto Baqué quanto Entler estão interessados em pensar e debater sobre essa produção plural e múltipla, que tem o fotográfico como parte ou essência e que ocupa esse lugar fragmentado, múltiplo e poroso do discurso da arte contemporânea.

\section{Para Dominique Baqué (2007), que} não está interessada em pensar todos os vieses da fotografia contemporânea, mas sim esse fotográfico que ocupa o contexto mesmo das artes visuais, a melhor forma foi designá- lo a partir do termo fotografia plástica (la photographie plasticienne). Como tantos outros pesquisadores ${ }^{6}$, Baqué encontra neste conceito um meio de

6 Nesse sentido, é importante resgatar o termo expandido, que fora cunhado por Cene Youngblood, no campo do cinema e por Rosalind Krauss, no campo da escultura, ainda na década de 1970, quando Baqué questiona a perda da base escultural e reflete sobre o esgarçamento dos limites do que poderia ser visto e considerado como escultura, transformando os parâmetros e paradigmas no campo da arte contemporânea désde então. Andreas Müller-Pohle (1985), partindo das ideias de Vilém Flusser - quando ele propõe, em sua Filosofia da Caixa Preta (1985), para os que não desejam ser funcionários de um sistema, uma ida além do conteúdo programático e técnico que a câmera-aparelho-máquina oferece,- , na década de 1980 utilizou pela primeira vez o termo expandido no campo do fotográfico, delimitando estratégias processuais que faziam uma imagem alocar-se no conceito que ele chamou de fotografia expandida, utilizado posteriormente na tese de Rubens Fernandes (1996). JáTadeu Chiarelli, na década de 1990 utilizou o termo fotografia contaminada para definir essas obras que passavam por diversas especificidades artísticas e desviavam-se de uma visão tradicionalista da fotografia. 
definir isso que se passa hoje, embora reconheça a dificuldade de enquadrar conceitualmente algo que revela-se

de mais a mais "leve", fluido, lábil, [...] como um tênue fio sem o qual a arte contemporânea perderia a sua flexibilidade e sua coerência.[...] Imagem de mais a mais móvel, rápida, que joga com os suportes, com as artes e com os deslocamentos de sentidos; imagem metamorfose também, porque hoje mais do que nunca o campo fotográfico revela-se plural, heterogêneo, irrompido, sem que seja possível unificá-lo, "suavizá-lo" - exceto por oposições e paradoxos (BAQUÉ, 2007$, p. 7$)^{7}$.

E é justamente partindo desta citação que encontro meu campo, minha hipótese mais enfática, que vem tomando corpo durante o desenvolvimento de minhas pesquisas em museus e seus acervos, assim como a partir de leituras, aulas e conversas com teóricos e pensadores do campo - ou dos campos - da fotografia e da arte contemporânea e, especialmente, a partir de conversas e da aproximação com artistas inseridos profundamente na discussão, a partir do que pensam e produzem. Caminho um pouco no sentido oposto ao que Ronaldo Entler (2009, p.?) propõe quando diz que

7 Tradução livre do francês.
Tanto faz se as imagens presentes nesta exposição poderiam ser tratadas também como pintura, design, instalação, performance, ou se poderiam ser bem, acolhidas em outras maisons que não a da fotografia. Não precisamos ser conservadores - sair em defesa do documento, da película, do laboratório, do enquadramento, da contemplação, do instante decisivo - para reconhecer que há sim uma história que confere, ainda hoje, um lugar à fotografia. Isso nãoé pouca coisa. Se não sabemos definir seus limites, a fotografia é, pelo menos, um lugar conceitual construído e consolidado no tempó, a partir de onde olhamos para uma produção artística, mais confortavelmente no caso de algumas obras, menos confortavelmente, no caso de outras. Seria legítimo, por exemplo, pensar Joel Peter Witkin a partir das referências da cenografia, Orlan, a partir da performance, Duane Michals, a partir do cinema, Vik Muniz, a partir do desenho, Ceorges Rousse, a partir da arquitetura; e ainda poderíamos recombinar ao infinito os autores e as linguagens aqui presentes... Mas escolhemos olhar para essas imagens a partir da fotografia, conceito que ainda ilumina tais experiências de modo muito produtivo. É possível romper com o purismo ontológico, é possível olhar criticamente para o passado, sem ter que negar o papel que certas referências exercem na produção e na fruição das imagens.

Prefiro pensar e conduzir o debate e aí resgato as exposições que apresento no início do texto -, a partir de 
outro ponto de vista e de estudos, que é o da arte contemporânea e, mais especificamente, o da fotografia inserida no discurso da arte contemporânea. 0 que quero afirmar é que, com raras exceções, o conjunto de obras apresentadas nestas exposições, que se questionam sobre o que é uma Fotografia ou sobre os limites do fotográfico, apresentam de fato uma outra situação, que não trata mais de fotografia; ou se
O que essas exposições e a grande parte das obras que as compõem apontam e demonstramé, na verdade, o que poderíamos entender e definir como estratégias da arte contemporânea: pela fragmentação e pela (des)ordenação no caos da contemporaneidade. Obras que carregam a marca do gesto, do processo, do construído, do peso de uma existência ou de um vazio. Obras que não desejam ser fotográficas, pictóricas, esculturais, ou isso ou aquilo. Obras que são múltiplas, porosas, escorregadias. E que dentro de uma perspectiva mais segura, poderão ser analisadas e compreendidas a partir de vieses especíquisermos dizer de outra forma, trata também de fotografia, mas vai além.

O que essas exposições e a grande parte das obras que as compõem apontam e demonstram é, na verdade, o que poderíamos entender e definir como estratégias da arte contemporânea.

Obviamente, não é simples lidar com essa constatação, em especial se esperamos ancoragem teórica e formal. Fica difícil enfrentar o desafio, se não estamos dispostos a encarar um campo que se atualiza o tempo todo, no desconhecido e no abismo aberto do indefinível. Obras e artistas marcados pela liquidez, ficos, passando a ser chamadas, talvez, de pintura, escultura e fotografia - enacrescidas de adjetivos como expandido, contaminado, híbrido. Isso releva as tentativas de alocação desșe tipo de fotografia num lugar de compreensão segura e garantida, que são, em primeiro lugar, consequências das características e das demandas de um contemporâneo fragmentado e fragmentário e de uma postura contemporânea assumida pelos artistas sensíveis às questões urgentes do hoje e do agora.

Acredito que Philippe Dubois vem compreendendo bem essas questões, tre outras possibilidades -, mas sempre 
seja nos cursos e seminários que ministra, quando trata das questões e características de uma imagem evento ou de um evento da imagem ${ }^{8}$, seja quando escreve sobre caminhos e novas teorias para a fotografia?. Mas também me parece que, já na década de 1990, quando após dez anos de lançamento da versão francesa, Dubois apresenta no Brasil a tradução do seu livro O Ato Fotográfico (1994), atualizado e acrescido de ensaios que já escapavam de suas discussões ontológicas e semióticas iniciais sobre a fotografia, o pesquisador já caminhava numa direção diferente da tratada aqui, mas que, de qualquer forma, nos abre caminhos quando discute as relações entre fotografia e arte contemporânea, e afirma o esgotamento de algumas questões impostas à fotografia desde sempre, exemplificando de diversas maneiras e a partir da produção e dá lógica criativa de vários artistas, por exemplo, o quanto se torna sem sentido pergun-

8 Em 2016, a partir da Bolsa Estágio Pesquisa no Exterior, concedida pela Fapesp, frequentei os seminários do grupo de pesquisa Lira (Laboratoire International de Recherche em Arts), dirigido por Dubois, na Univesité Sorbonne Nouvelle - Paris 3, e frequentei a disciplina La notion d'événement d'image. Formes et enjeux d'une esthétique de la plasticité visuelle, ministrada por ele no segundo semestre (primeiro semestre pelo calendário escolar francês) do ano.

9 Ver Dúbois (2016). tar se fotografia é ou não é arte. Partindo de Marcel Duchamp e passando por nomes como El Lissitzky, Kasemir Maliévitch, Jackson Pollock, Robert Rauschenberg e Yves Klein, entre outros artistas, Dubois demonstra que, de alguma forma, as obras de arte produzidas na contemporaneidade se impregnaram das estratégias e dos princípios do fotográfico, em especial desde Duchamp que, assim como todos artistas contemporâneos, com sua gama múltipla e complexa de obras, extrai estratégias de renovação de seus processos criativos, de certa epistemologia do fotográfico (DUBOIS, 1994, p. 258).

A arte de Duchamp e a fotografia têm em comum funcionarem, em seu princípio constitutivo, não tanto como uma imagem mimética, analógica, mas, em primeiro lugar como simples impressão de uma presença, como marca, sinal, sintoma, como traço físico de um estar-aí (ou de um ter-estado-aî): uma impressão que não extrai o seu sentido de si mesma, mas antes da relação existencial - e muitas vezes opaca - que a une ao que a provocou (DUBOIS, 1994, p. 257).

Assim, naquele momento, Dubois (1994, p. 253-254) propõe e defende a hipótese de que a arte, a partir do século $X X$, insistirá em marcar-se em 
seus fundamentos pela fotografia, impregnando-se de suas lógicas formais, conceituais e perceptivas. A arte contemporânea é, nesta perspectiva, definida e marcada pelo ato: de produção. É, portanto, marcada pela questão processual, sendo o resultado final, isto é, a obra em si, apenas um traço ou um índice do que é ou do que foi um processo, que é artístico e criativo, mas também existencial.

De fato, no capítulo seis do livro, Dubois (1994) está propondo uma reflexão sobre a arte do modernismo e da contemporaneidade, e sobre o papel e protagonismo da fotografia nesse novo tempo histórico e artístico, muito mais do que uma discussão sobre fotografia enquanto especificidade, embora mantenha ainda certa preocupação com uma discussão ontológica do meio, hoje já questionada por ele mesmo e tantos outros pesquisadores do campo - e questionada também pelos espaços de difusão e exposições aqui analisadas, especialmente pela proposta de Clément Chéroux, no Centre Ceorges Pompidou: Qu'est ce que la photographie?

Dubois e Vilém Flusser - quando em sua Filosofia da Caixa Preta (1985) propõe que o operador construa jogos de inteligência com o sistema, superando-o em sua programação - talvez tenham percebido, por caminhos diferentes, as mesmas transformações e mutações que vinham ganhando força no campo da arte e que eram indissociáveis da própria história dos meios e das especificidades.

Ese temos que definir a fotografia ontologicamente em algum momento, já sabemos que, apesar de relativa, como demonstra claramente a exposição Qu'est ce que la photographie?, essa (hão) ontologia pode ser melhor compreendida a partir de características fundamentais, como a porosidade, a maleabilidade, a mobilidade e o múltiplo. Características "de berço" da fotografia, que cónseguimos contemplar nos jogos imagéticos propostos por Hippolyte. Bayard, desde seus autorretratos construídos cenicamente - dentre os quais se destaca Noyé (1840), em que ele exacerba a relação entre fotografia, texto escrito e teatralidade ou encenação, e que, segundo Michel Poivert (2015, p. 45), institui de maneira inaugural o paradigma teatral na fotografia - até suas fotos de esculturas, que propunham diferentes 
ângulos retomando a ideia do tridimensional no formato bidimensional do suporte fotográfico.

Essas características fazem com que Dominique Baqué (2008) identifique a fotografia como o tênue fio condutor que permite à arte contemporânea manter sua flexibilidade e coerência, e foram entendidas por Dubois (1994) como princípios norteadores para a renovação e recondução dos caminhos da arte, incorporados por toda a arte a partir de determinado momento histórico. Também permitem que as fotografias, assim como as pinturas e esculturas, continuem existindo em suas especificidades (desde sempre e também na contemporaneidade), e, fundamentalmente, que ocorra a abertura das modalidades para os entrelaçamentos, os deslocamentos de sentido, de tempo e de espaço, para a fragmentação e diálogos entre imagens e entre processos, sem preocupar-se com definições específicas e lu-, gares próprios, para além de um não lugar mesmo, que é o que caracteriza uma grande parte da produção contemporânea desenvolvida por artistas.

Não é mais e apenas sobre fotografia que estamos falando. Estamos falando sobre arte contemporânea, suas estratégias, seus discursos, suas experiências e suas demandas. Nesse sentido, e considerando as exposições aqui apresentadas, um segundo passo, seria, então, discutir esses processos e analisar quais são essas estratégias e discursos.

Entretanto, poragora, e primordialmente, o que nos cabe, de maneira urgente e essencial, éjustamentefazer a pergunta no seu inverso: O que não é fotografia?

\section{Referências}

BAQUÉ, Dominique. Cartographie Contemporaine. In: TAITTINGER, T. Qu'est ce que la photographie aujourd'hui. Paris: Beaux Arts Éditions, 2007. p. 6-13.

Photographie plasticienne: un art paradoxal. Paris: Regard, 1998.

Photographie plasticienne, l'extreme contemporain. Paris: Regard, 2004. 
CHEROUX, Clément; ZIEBINSKA-LEWANDOWSKA, Karolina. Qu'est ce que la photographie? Paris: Centre Pompidou, 2015.

CHIARELLI, Tadeu. A fotografia contaminada: In: Arte Internacional Brasileira. São Paulo:, Lemos, 1999.

DUBOIS, Philippe. De l'image-trace à l'image-fiction. Le mouvement des théories de la photographie de 1980 à nos jours. Études Photographiques, [S.I - online], n. 34, p. 53-69, 2016. Disponível em: <http://etudesphotographiques.revues.org/3593>. Acesso em: jan. 2017.

\section{O ato fotográfico e outros ensaios. Campinas: Papirus, 1994}

ENTLER, Ronaldo. (2009). Um lugar chamado fotografia, uma postura chamada contemporânea. Disponível em: <http://www.entler.com.br/textos/postura_contemporanea.html>. Acesso em: 19 jan. 2017.

FERNANDES, Rubens. Processos de criação da fotografia: apontamentos para o entendimento dos vetores e das variáveis da produção fotográfica. Facom - Revista da Faculdade de Comunicação da FAAP, São Paúlo, n. 16, p. 10-19, jul./dez. 2006. Disponivel em: <http://www.faap.br/ revista_faap/revista_facom/facom_16/rubens.pdf>. Acesso em: jul. 2017.

FLUSSER, Vilém. Filosofia da caixa preta: ensaios para uma futura filosofia da fotografia. São Paulo: Hucitec, 1985.

LEMACNY, Jean-Claude. La. Photographie créative. Paris: Contrejour, 1984.

MUSEU DE ARTE MODERNA DE SÃO PAULO. Coleção online. Fabiana Rossarola. Sem título [fotocópia e costura sobre tecido estofado de fibra sintética], 1999. Disponível em: <http:// mam.org.br/acervo/2000-302-rossarola-fabiana/>. Acesso em: ago. 2017.

MUSEU DE ARTE MODERNA DE SÃO PAULO. Coleção online. Rosana Paulino. Sem título [xerografia e linha sobre tecido montado em bastidor], 1997. Disponível em <http://mam.org. br/acervo/1997-076-000-paulino-rosana/>. Acesso em: ago. 2017.

MÜLLER-POHLE Andreas. Information Strategies. Trad. Jean. Säfken. European Photography 27, V. 6, n. . jan./mar. 1985 .

NATIONAL GALLERY OF AUTRALIA. International painting and sculpture [catálogo online]. Lucas Samaras. Box no. 68 [fotografia de obra original: pintura polímera sintética sobre madeira], 1968. Disponível em: <https://nga.gov.au/International/Catalogue/Detail. cfm?IRN=32434>. Acesso em: ago: 2017

POIVERT, Michel. Un mort aux origines de la photographie. In: Brève Histoire de la Photographie. Paris: Hazan, 2015. p. 34-47 
La photographie contemporaine: un moment de l'histoire? In Brève Histoire de la. Photographie. Paris: Hazan, 2015. p. 180-1.97.

SQUIERS, Carol (Org.). Whats is a photograph? New York: Prestel, 2014. 256 p. Catálogo de exposição, 31 de janeiro de 2014 a 04 de maio de 2014, International Center of Photography.

\section{Entrevistas não publicadas}

CHÉROUX, Clément. Entrevista concedida a Paula Cabral Tacca. Paris, 27 set. 2016 CINTRÃO, Rejane. Entrevista concedida a Paula Cabral Tacca. São Paulo, 22 set. 2015. . 


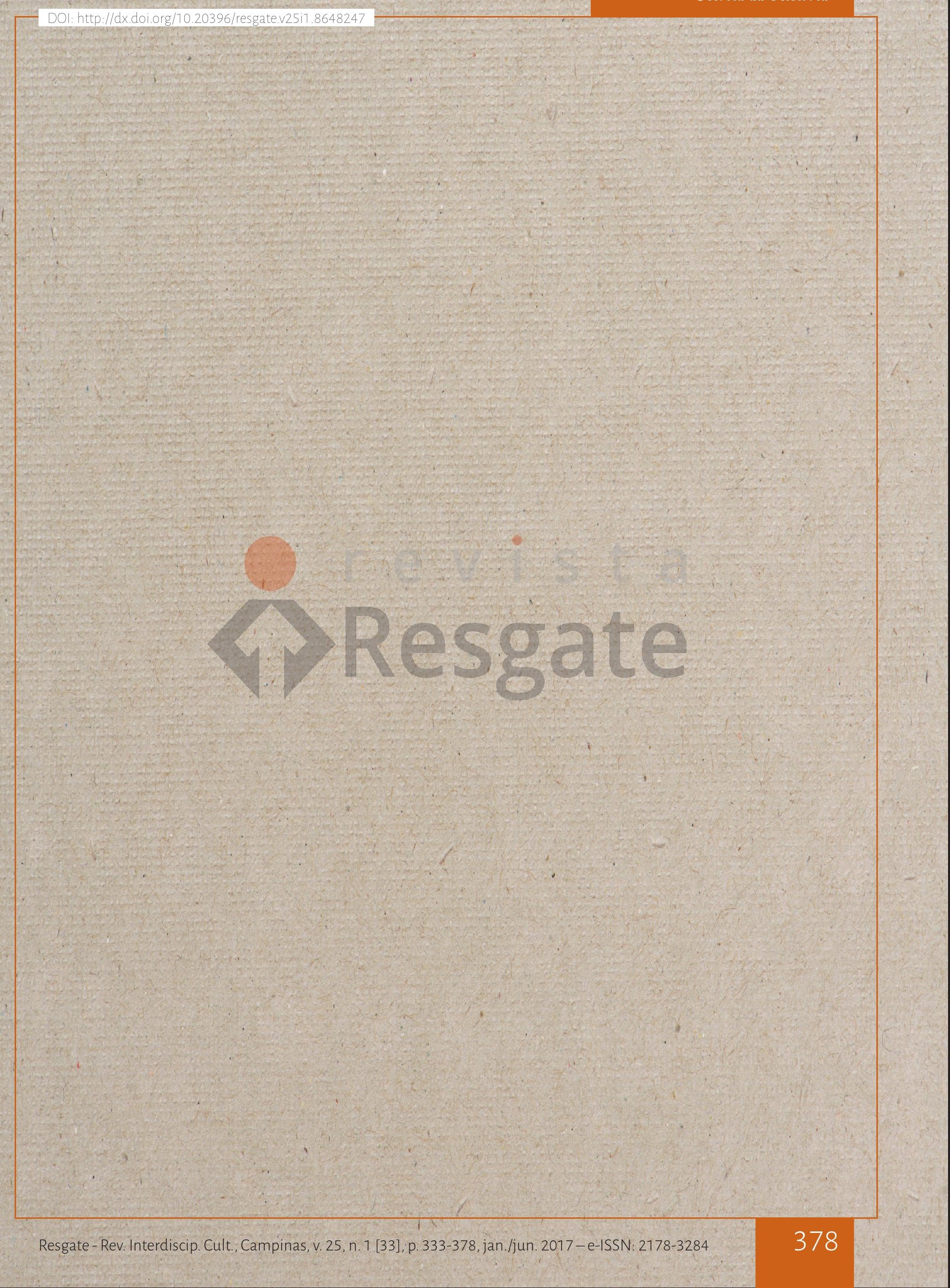

